Historic, Archive Document

Do not assume content reflects current scientific knowledge, policies, or practices. 




\title{
GOLD MEDAL BULBS
}

\section{AND PLANTS FOR FALL PLANTING} W $\mathrm{E}$ present herewith our annual fall catalog of bulbs and plants for fall planting, in which will
be found the most complete list of the finest bulbs offered in America. This season we are offering several additional types of the newer tulips, and we want to call especial attention to the newest and most meritorious of all, the "Ideal Darwins." These are cousins to the best Darwins, which they resemble, but which they surpass in a greater variation in color and soft color tones, and in size and vigor as well. The newest and most sensational of all "The Grullemani" are offered for the first time, also "Triumphs" and "Mendels." These will be found described and listed elsewhere.

To those who saw our exhibits at the National Flower Show in 1930 and our exhibits at our store, greenhouses and nurseries in 1931, and to our customers who have grown our bulbs, we do not need to enthuse on the quality of our bulbs, but those who may have missed seeing these wonderful flowers, we cordially invite to visit our displays this coming winter and spring, and to see the world's finest in bulbous flowers.

\section{PRICES GREATLY REDUCED}

This year too, the prices of the finer tulip bulbs have been greatly reduced. A comparison will show that in many instances the cost is only slightly over half of that of last year. In fact, bulbs have never been as low in price as they are this season.

Quality Always Counts-Keep in mind when buying bulbs that it is results that count, and that your best guarantee of satisfaction is to purchase them from a reliable source. Our policy has always been to supply our customers with the very best materials obtainable in every branch of our business. This is more essential with bulbs than with most any other article as it is most important that bulbs be properly grown and cured in order to produce their best. Bulbs of the same kind may look nearly alike to the average person, but may be very different to one with expert knowledge.

The bulbs we offer will be selected top size, and the very best obtainable.

Service-A complete horticultural service is available to all our friends and customers at all times. This is made possible by our large organization of trained experts in various departments of our business, who will cheerfully advise you on any problem.

\section{Four of Our Ninety-One First Awards at the National Flower Show, 1930}

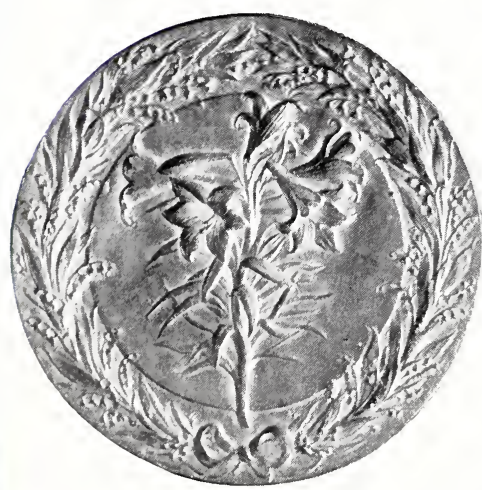

Gold Medal of the American Bulb Company. Awarded for choicest and best collection of Lilies.
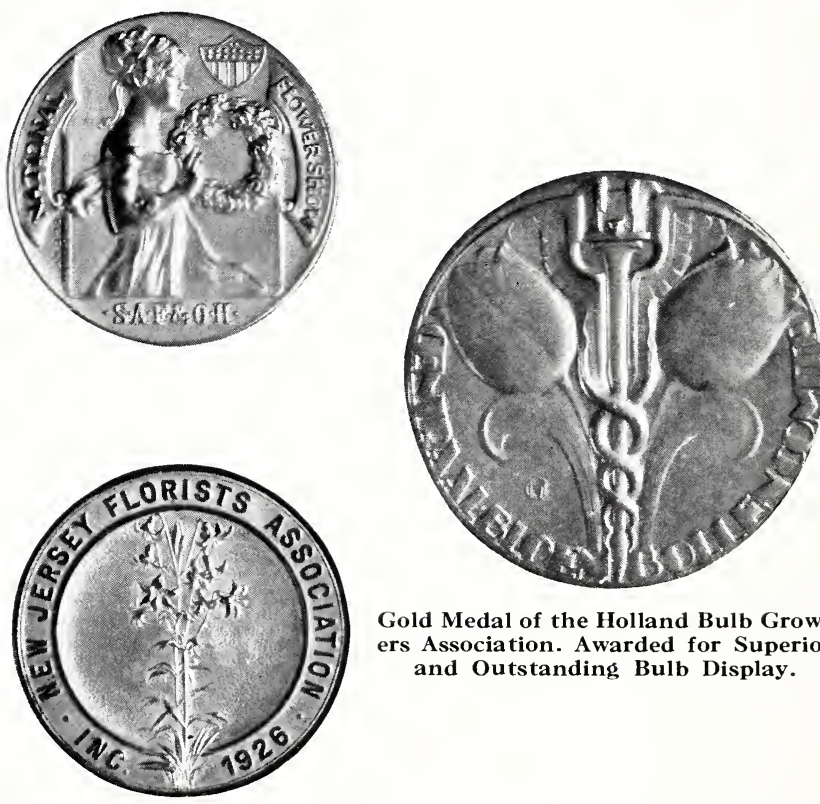

Gold Medal of the Holland Bulb Growers Association. Awarded for Superior and Outstanding Bulb Display.

\begin{abstract}
(Upper Center) Silver Medal of the Society of American Florists and Ornamental Horticulturists Awarded for excellency in display of blooming shrubs and perennials.
\end{abstract}

(Lower Center) Gold Medal of the New Jersey Florists Association Awarded for display of Rose Garden.

Our total of First Prize Awards at Competitive Exhibitions is over TWELVE HUNDRED, and include many trophies of Medals, Cups, Shields, Banners, Blue Ribbons, Etc.-THERE IS A REASON 


\section{"Ideal Tulips"}

$\mathrm{T}$ HIS new class of tulips is a development of the hybridizers art, the result of which is a more refined and quite distinct flower of the Darwin type.

The outstanding difference between Ideals and Darwins is in the softer color tones in the Ideals. In many of them the coloring is of the so termed pastel shades or tints, while some are pure white, in direct contrast with the deep and vivid colors of the true Darwins.

The size of flowers average larger and their habit of growth differs from the Darwins in that the flowers are borne on more wiry stems, making them appear more graceful.

Their lasting qualities both in the garden and after being cut is very marked. "Ideals" show a big superiority in this respect to most other tulips.

The blooming time is a week to ten days earlier than Darwins outdoors. In the greenhouse they may be forced with the earliest Darwins

"Ideals" are of free and robust habit in growth and when planted they should be given a liberal amount of fertilizer, preferably old cattle manure, but lacking this bone meal or any standard fertilizer may be used. Close attention to this will bring surprising results.

Abd-El-Krim-A monstrous, dark purplish-red flower, Each Doz, 100

tall, stiff stem. The largest tulip in this color. Height $28^{\prime \prime}$..\$0.50 $\$ 5.00$

Bella Donna-Ideal in form, very large flower. Color is a lovely satiny crimson-red. Strong stem. Height $28^{\prime \prime} \ldots \ldots \ldots .50 \quad \mathbf{5 . 0 0}$

Benjamin Franklin-A perfectly formed pure white flower of the largest size borne on strong stem. Height $27^{\prime \prime} \ldots .$.

Blue Danube-Deep bluish-purple with greyish-blue suffusion, inside of petals bluish violet, blue and white center. Large flower of fine substance. Height $29^{\prime \prime}$.

Camelia-Lovely satiny rose-pink flower with large white base, oval shaped on strong stem. Height $27^{\prime \prime}$

Cattleya-A beautiful lavender flower with pink suffusion, that brings to mind a Cattleya Orchid, large finely formed flower on strong stem. Height $27^{\prime \prime}$.

Cherry Pink-Bright cherry blossom pink flowers with white edging. Large flower, shaped like a large pink rosebud. Height $27^{\prime \prime}$

Foam-A very large perfectly formed flower of the purest white and with intense black anthers. Has great substance white and with intense black anthers. Has great substance

Heliotrope-The color is clear heliotrope, of a most refined appearance. Height $26^{\prime \prime}$

Lady Pirrie - Bright satiny deep rose red, broadly edged rose pink, with white base. Large flower on fine stiff stem. Height 24"

La Tosca-Beautiful large, oval, soft creamy yellow flower, deepening at edges, yellow base. Strong growing. Height

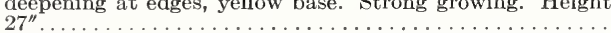

Lavender King-Finely formed flower, satiny lavender on outside of petals, clear rosy-lavender inside with white base. Strong stem. Height $24^{\prime \prime}$.

Lilac Wonder-The color is quite unique in tulips. Porcelain lilac is as near a description of the beautiful color as we can think of. Large finely formed flowers on strong stems. Height $26^{\prime \prime}$.

Margaux-A tremendous sized oval shaped flower, the color a deep wine red with a broad edge of lighter color, blue base, on very strong stem. Height $33^{\prime \prime}$.

Mascotte-A most refined appearing flower. The color is a blending of orange and salmon with yellow center. Stiff wiry blending of orange and salmon with yellow center. Stiff wiry

stem. Hermaid-A beautiful large oval flower, color is a delicate Mermaid-A beautiful large oval flower, color is a delicate
rose pink, edges of petals lighter, creamy white base. Strong, tall stem. Height $30^{\prime \prime}$. (See illustration).

Mrs. Mandel-Violet-blue with lilac flush, large white base. Very large finely formed flower. Height $27^{\prime \prime}$

Mrs. Watt-Very deep luminous wine-red with very large blue and white base. Height $25^{\prime \prime}$. .

Muriel-A tulip of unusual color and form. Clear reddishviolet, white base, large oval flower with outer petals reflexing when fully open. Height $25^{\prime \prime} \ldots \ldots \ldots \ldots \ldots \ldots \ldots$.

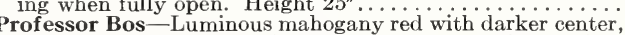
rof essor Bos-Luminous mahogany red with darker center,

Proserpina-Very large oval flower with reflexing petals. Color is deep rosy carmine, sweet scented, strong stems. Height $30^{\prime \prime}$

Red Emperor - Color is a most brilliant vermillion red and large blue center, large showy flower. Height $29^{\prime \prime}$

Rose Glory-A glorious deep rose-pink flower with lighter flush at edges, white center, large finely formed flower. Height $30^{\prime \prime}$

Shot Silk-A beautiful pure white flower with a silky-silvery sheen, white anthers. Strong, wiry stem. Height $24^{\prime \prime}$. .

Sonia-Vermillion-red with salmon flush, inside of flower is

Sonia-Vermillion-red with salmon flush, inside of flower is

\section{$20 \quad 2.00 \quad \$ 15.00$}

606.00

$40 \quad 4.00$

30.00

$.75 \quad 8.00$

$.20 \quad 2.00$

15.00

$.25 \quad 2.50$

18.00

$50 \quad 5.00$

37.50

$.75 \quad 8.00$

.758 .00

$1.00 \quad 10.00$

$.40 \quad 4.00$

27.50

$1.00 \quad 10.00$

.60

\section{.50}

.20

.20

20

.50

.75

.25

.50

.50

.75

.75

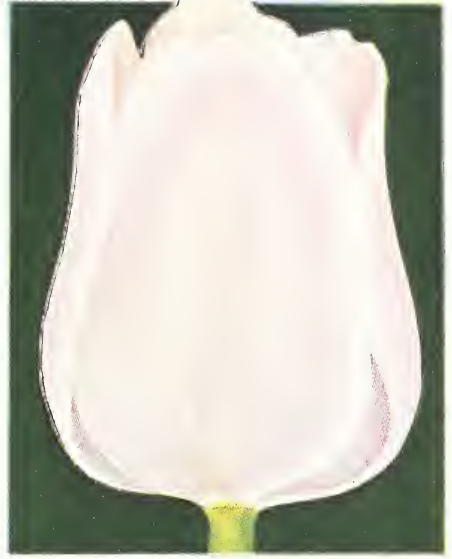

Mermaid

Springtime - Beautiful large wine-red flower with blue center. This tulip lasts 3 to 4 weeks either in garden or when cut. Height $24^{\prime \prime}$

Each 50c; Per Doz. \$5.00

Sweetheart-Delicate soft rose-pink with white base. A most pleasing tulip. Tall, stiff stem. Height $27^{\prime \prime}$

Each 50c; Per Doz. $\$ 5.00$

Tillie Luss - A bright rosy-purple flower with greyish center. Large pointed flower with great substance. Height $27^{\prime \prime}$.

Each 40c; Per Doz. \$4.00; Per $100 \$ 27.50$

Tokay - We consider this tulip as most outstanding. In size it is not surpassed by any and the color is a very pleasing lavender with a reddish flush. Height $33^{\prime \prime}$.

Each .40c; Per Doz. \$4.00; Per $100 \$ 27.50$ (See Illustration)

White Giant - The perfect white tulip. the form of the giant flower is ideal and the substance is wonderfully fine. Height $33^{\prime \prime}$. Each 50c; Per Doz. $\$ 5.00$

Winnifred Walker-Color is a glowing salmon, with a scarlet flush, clear blue base. Large oblong flower on strong stem. Height $30^{\prime \prime}$

Each $\$ 1.50 ;$ Per Doz. $\$ 15.00$

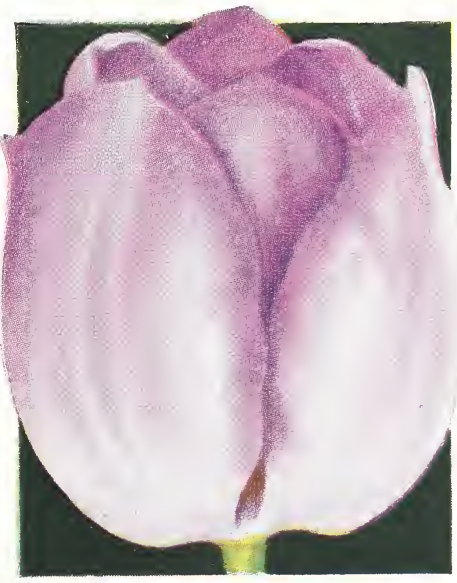

Tokay 


\section{Darwin Tulips}

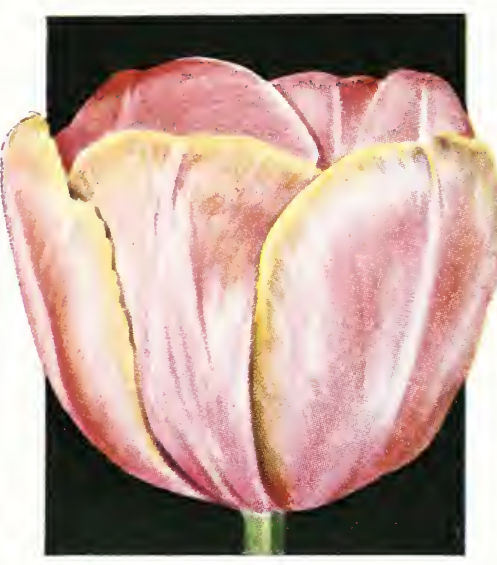

Afterglow

Doz. 100

Afterglow-Rosy pink with orange and salmon suffusion. tion and unique in Darwins. tion and unique in Darwins. Height $26^{\prime \prime}$ (See Illustration)

$\$ 0.75 \$ 6.00$

Allard Pierson-Deep crimson-maroon, very early blooming. Height $26^{\prime \prime} \ldots$.

Anton Roozen-Vivid rosepink with white base and blue markings. Very large cup shaped flower. Height

Apple Blossom-Beautiful soft rose pink suffusion on faint pearly pink ground. This is a new variety of the most refined coloring. Large flower on good stem. Height $28^{\prime \prime}$. Each \$0.30

Aviator Hawks-Deep rosepink, margined pale rose. beautifully formed flower on strong, tall stem. Height $30^{\prime \prime} \mathbf{3 . 0 0}$

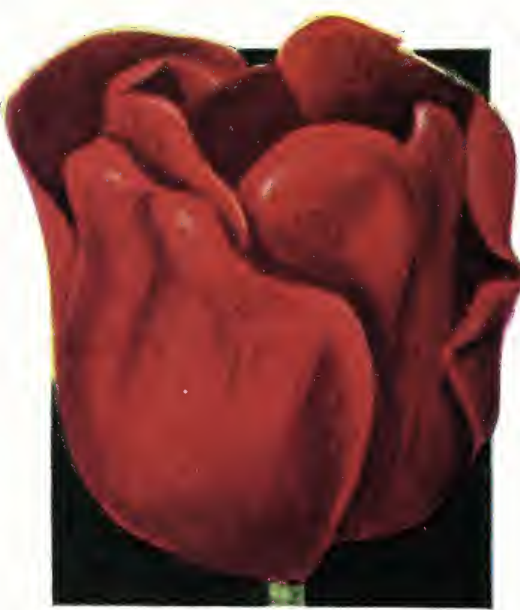

City of Haarlem
7 HE Darwins are a development through hybridization of the old

Bi-bloom types, and were first originated in France, but have been greatly improved and developed in Holland in the past twenty to thirty years. Darwins are as a whole the best known of the late flowering group, and are considered the "Aristocrats" of Tulipdom. Darwins do not vary in type and shape as much as the other species, but make up for this in their greater brilliance and intense colors, which range from the deepest violet, maroon and crimson to the most delicate shades of pearl and pure white.

Plant the bulbs as closely as desired, about six inches deep, before the sharp frosts harden the ground. Before snow comes to stay, cover well with leaves or straw. Remove this covering in the spring as soon as it is free from snow and ice.

The list of kinds we offer is most complete, all the newer meritorious varieties as well as all the best of the older kinds will be found in this list. All the bulbs we offer are "Top Size," the kind that produce results. We do not and will not handle the culls and inferior grades that are offered at sale prices.

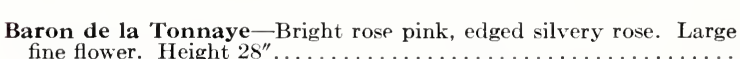
fine flower. Height $28^{\prime \prime} \ldots \ldots \ldots \ldots \ldots \ldots \ldots \ldots \ldots \ldots \ldots \ldots \ldots \ldots \ldots \ldots \ldots \ldots \ldots$

Bartigon-Dazzling, fiery scarlet-crimson, white base with blue ring.
Very early blooming. Height $28^{\prime \prime} \ldots \ldots \ldots \ldots \ldots \ldots \ldots \ldots \ldots \ldots \ldots \ldots \ldots$ Very early blooming. Height $28^{\prime \prime} \ldots \ldots \ldots \ldots \ldots \ldots \ldots \ldots \ldots \ldots \ldots \ldots$ starred blue, inside of flower deeper color. Height $25^{\prime \prime} \ldots \ldots \ldots \ldots$.

Burgomeister Sandberg-Deep crimson with a velvety brown tone and deep blue base, an enormous beautifully formed flower on

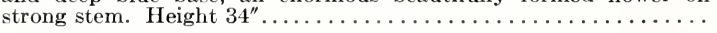

Centenaire-Rich violet-rose with large blue base. An enormous flower on tall, strong stem. Height $30^{\prime \prime} \ldots \ldots \ldots \ldots \ldots \ldots \ldots \ldots$

Chant d'Cygne-Glowing salmon-scarlet, flushed soft rose. A wonderful large brilliant flower. Height $28^{\prime \prime} \ldots \ldots \ldots \ldots \ldots \ldots \ldots \ldots . . .1 .00$

City of Haarlem-Intense, rich deep scarlet with steel blue base. We consider this the finest and largest tulip in this color. A wonderful large flower. Height $28^{\prime \prime} \ldots \ldots \ldots \ldots \ldots \ldots \ldots \ldots \ldots \ldots \ldots$ (See Illustration)

Clara Butt-Rosy-salmon with blue base and white halo. Medium sized flower. Height $24^{\prime \prime} \ldots \ldots \ldots \ldots \ldots \ldots \ldots \ldots \ldots \ldots \ldots \ldots \ldots \ldots . .60$

Dream-Soft heliotrope-lilac, inside rosy violet. Height $26^{\prime \prime} \ldots \ldots \ldots . .60$

Duchess of Westminster (See Yolande)

Eclipse-Glowing blood red with blue base. Very large flower on good stem. Height $28^{\prime \prime} \ldots \ldots \ldots \ldots \ldots \ldots \ldots \ldots \ldots \ldots \ldots \ldots . \ldots \ldots$

Europe-Salmon-scarlet, rose shadings with white base. Medium size flower, strong stem. Height $22^{\prime \prime} \ldots \ldots \ldots \ldots \ldots \ldots \ldots \ldots \ldots \ldots \ldots$

Farncombe Sanders-Brilliant rose-scarlet with clear white base. Large broad petaled flower of perfect form. Height $30^{\prime \prime} \ldots \ldots \ldots \ldots$.

Fashion (See Mrs. Potter Palmer)

Faust-Deep satiny purple with white base. Very large flower. The best in this color. Height $30^{\prime \prime} \ldots \ldots \ldots \ldots \ldots \ldots \ldots \ldots \ldots \ldots \ldots$

Feu Brilliant-Intense, clear scarlet. Very large beautifully shaped

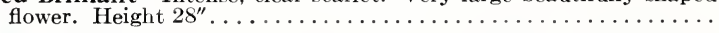

Frans Hals - Bright bluish violet. Very large finely formed flower. Should be planted in partial shade as too strong sun is apt to injure the rich color. Height $28^{\prime \prime} \ldots \ldots \ldots \ldots \ldots \ldots \ldots \ldots \ldots \ldots \ldots \ldots \ldots \ldots \ldots 1.00$

Giant-Glowing reddish purple, suff used with dark violet, white base. A giant flower on strong stem. Height $30^{\prime \prime} \ldots \ldots \ldots \ldots \ldots \ldots \ldots . .25$

Glow-Dazzling vermillion-scarlet, with white base. Finely formed flower on good stem. Height $28^{\prime \prime} \ldots \ldots \ldots \ldots \ldots \ldots \ldots \ldots \ldots \ldots \ldots .6 \ldots$

Golden Wonder-Brownish orange turning to a golden yellow as flower develops fully. Very unique color in Darwins. Medium sized

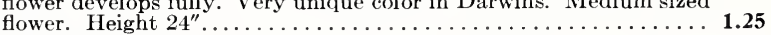

Herodiade (Rudolf Valentino) - Lilac-rose, large flower on medium

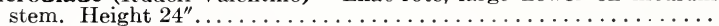

Jubilee-Deep bluish purple with white base. A wonderful large finely formed flower. The very best in this color. Height $30^{\prime \prime} \ldots \ldots . \mathbf{1 . 2 5}$ (See Illustration Next Page)

King George V-Brilliant cherry red, inside brilliant orange-scarlet, blue base. A very outstanding variety. Immense flowers of unusual substance on tall, strong stems. Height $28^{\prime \prime} \ldots \ldots \ldots \ldots \ldots \ldots \ldots \ldots 1.50$ 


\section{Darwin Tulips}

King Harold-Deep blood red., A magnificent flower of the largest

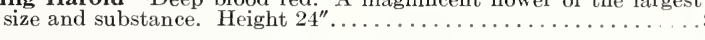

La Fiancee-Deep rose shading to old rose, petals edged soft pink, blue base. A very large, finely formed flower on tall stem. Height $30^{\prime \prime} \mathbf{1 . 0 0}$

La Tulipe Noir-Deep velvety maroon black. Large flower. The blackest of all tulips. Height $26^{\prime \prime} \ldots \ldots \ldots \ldots \ldots \ldots \ldots \ldots \ldots \ldots . .85$

Le Notre-Bright rosy pink with white base and blue halo, finely formed flower on good stem. Height $26^{\prime \prime} \ldots \ldots \ldots \ldots \ldots \ldots \ldots \ldots$

Madame Krelage-Lilac-rose, petals margined silvery rose, soft rose inside of flower. Large fine flower. Height $30^{\prime \prime} \ldots \ldots \ldots \ldots \ldots$

Matchless (Roi d'Islande)-Beautiful deep lilac-rose, petals edged pale rose. Large flower on very strong stem. Height $22^{\prime \prime} \ldots . . . \ldots$.

Mrs. Potter Palmer (Fashion)-Deep, rich purple. A very fine

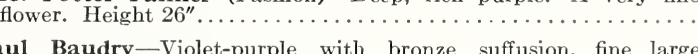

Paul Baudry-Violet-purple with bronze suffusion, fine large flower on strong stem. Height $28^{\prime \prime} \ldots \ldots \ldots \ldots \ldots \ldots \ldots \ldots \ldots \ldots \ldots$

President Taft-Deep crimson-maroon, a superb tulip of the largest
size on strong stem. Height $28^{\prime \prime}$. Pride of Haarlem-Brilliant rose-carmine, with blue base. Tremendous flower on strong stem. Height $30^{\prime \prime} \ldots \ldots \ldots \ldots \ldots \ldots \ldots \ldots$

Prince of the Netherlands - Glowing cerise-scarlet, edged rose with blue base. Very large flower of greatest merit. Height $32^{\prime \prime} . . .$. .

$$
\text { (See Illustration) }
$$

Prince of Wales - Glowing rose-pink with scarlet flush and blue base. A very large flower on strong stem. Height $28^{\prime \prime} \ldots \ldots \ldots \ldots \ldots \ldots$

Princess Elizabeth-Brilliant pink, changing with age into soft rose pink, white base. One of the outstanding Darwins. Height $26^{\prime \prime}$...

Prof. Rauwenhoff-Bright cherry red, inside glowing scarlet with blue center. Large flower on strong stem. Height $28^{\prime \prime} \ldots \ldots \ldots \ldots \ldots$

Rev. d'Ombrain-Fiery crimson red, inside currant red with blackish blue base, a wonderfully brilliant flower. Height $28^{\prime \prime} \ldots \ldots \ldots \ldots .1 .00$

Rev. Ewbank - Soft lavender mauve, with lighter margins, white base

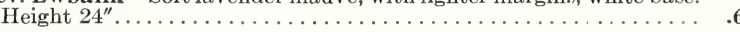

Roi d'Islande (See Matchless)|

Rudolf Valentino (See Herodiade)

Scarlet Beauty-Glowing vermillion-scarlet. Enormous flower on tall, strong stem. Height $26^{\prime \prime} \ldots \ldots \ldots \ldots \ldots \ldots \ldots \ldots \ldots \ldots \ldots . .65$

Spohr-Silky lilac-purple with white and blue base, large beautifully shaped flower on strong erect stem. Height $26^{\prime \prime} \ldots \ldots \ldots \ldots \ldots \ldots$

Sundew-Deep scarlet-crimson, the petals are edged with a hairy crest that is very unique. The flowers are large and very striking, opening into a saucer shape. Height of stem $22^{\prime \prime} \ldots \ldots \ldots \ldots \ldots \ldots, 1.75$

The Bishop-Deep, rich violet with dull blue base and white halo. An enormous flower on very strong stem. Height $30^{\prime \prime}$. Each $\$ \mathbf{0 . 5 0}$.

Valentine - Soft heliotrope with violet shading, white base, a splendid flower on good stem. Height $34^{\prime \prime} \ldots \ldots \ldots \ldots \ldots \ldots \ldots \ldots \ldots$

Venus-Beautiful lilac-rose, inside clear rose with white base. A most pleasing and dainty color. Height $30^{\prime \prime} \ldots \ldots \ldots \ldots \ldots \ldots$

Victoire d'Oliveira-Deep carmine with maroon suffusion. Fine early blooming tulip. Height $26^{\prime \prime} \ldots \ldots \ldots \ldots \ldots \ldots \ldots \ldots \ldots \ldots$

Virully Verbrugge-Bright rosy-carmine with white base starred

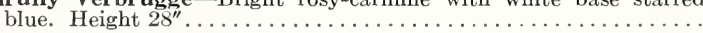

White Queen (Le Candeur) - White with very delicate pink flush. A fine medium sized flower on strong stem. Height $24^{\prime \prime} \ldots \ldots \ldots$.

Wm. Copeland-Rosy-lilac. A very fine early flowering Darwin. Desirable for indoor culture as it forces easily. Height $24^{\prime \prime}$. .

Wm. Pitt-Deep, brilliant crimson-scarlet, suffused with a purplish sheen. Deservedly a very popular tulip. Large flower on strong

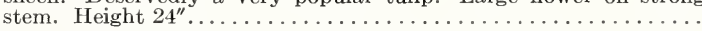

Yellow Darwin (Inglescombe Yellow) - Glossy canary yellow. This is not a true Darwin but we include it among the Darwins as it

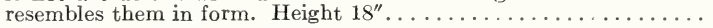

Yolande (Duchess of Westminster) - Soft rose, inside brilliant salmon-rose with yellowish base. Large flower strong stem. This is a vastly improved Clara Butt. Height $27^{\prime \prime}$................ 2.0

Zulu-Glistening blackish-purple. Large egg-shaped flower. Often called the black tulip. Height $28^{\prime \prime} \ldots \ldots \ldots \ldots \ldots \ldots \ldots \ldots \ldots \ldots \ldots$

NOTE-Add $5 \mathrm{c}$ per dozen for all tulips to be sent by parcel post
100

$\$ 5.00$

7.50

6.50

4.50

5.00

5.50

6.00

7.00

7.00

4.50

5.50

10.00

4.50

5.00

7.50

4.50

6.50

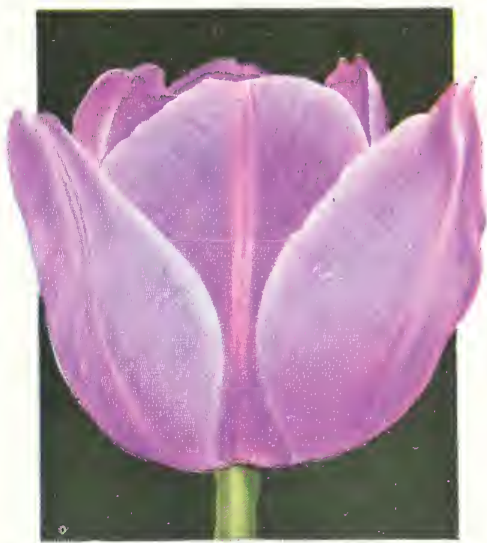

Jubilee (See Page 4)

\section{H. \& O. SPECIAL MIXTURE OF DARWIN TULIPS}

This mixture is made up for us by the largest grower of Darwin Tulips in Holland, and is composed of great variety of fine kinds, 50c per dozen,

$\$ 3.75$ per 100 .

By parcel post prepaid, 55c per dozen, $\$ 4.00$ per 100 .

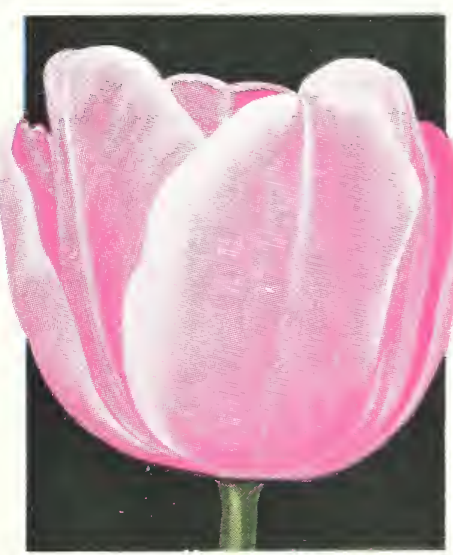

Prince of the Netherlands 


\section{Breeder Tulips}

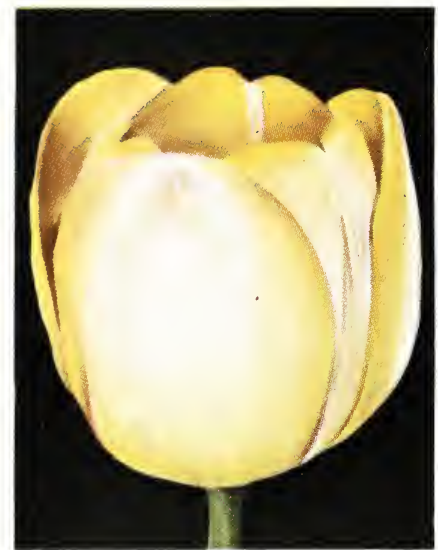

Jaune d'Oeuf

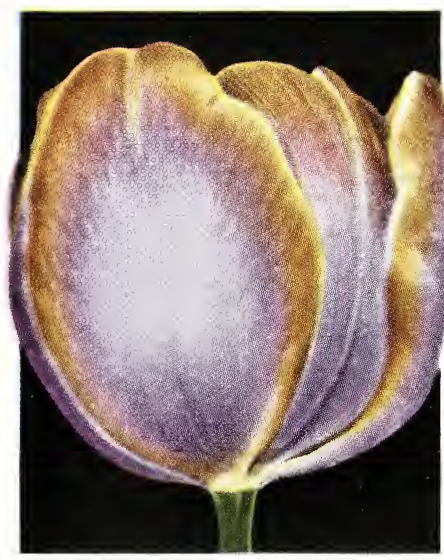

Louis XIV

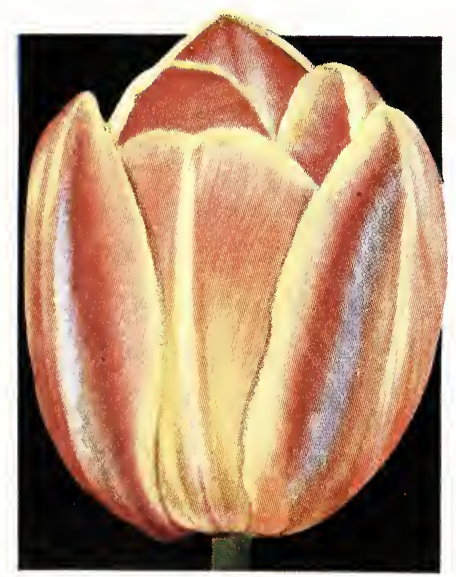

Lucifer
THIS class comprises mainly the old original or mother tulips that were favorites in Holland centuries ago, and from which many of the newer types and species have been bred and developed.

They are very robust in habit of growth. Their size and great lasting qualities makes them unusually well suited for the garden.

The predominating colors are rich bronze, buff, brownish and purple tones, which is overlaid with a silvery sheen or bloom such as is seen on fruits.

Many of them are sweet scented. The time required for the development of the great flowers makes their blooming season later than most other kinds. They require the same cultural direction as the Darwins.

Doz. $\quad 100$

Abd-el-Kader-Deep bronze shading to pale bronze at edge of petals, inside bronzy brown with yellowish base. A beautiful large and distinctive flower.

Height $30^{\prime \prime}$

$\$ 10.00$

Apricot-Golden buff, suffused with ruddy apricot. Height 26"

Bacchus - Deep reddish violet, shading to blue with white base. Very large egg shaped flower. Height $32^{\prime \prime} \mathbf{1 . 0 0}$

Bernadotte-Lilac with beautiful blue and bronze suffusion. Very large flower. Height $28^{\prime \prime} \ldots \ldots \ldots \ldots$.

Bronze Queen-Soft buff, with golden bronze suffusion inside of flower. Height $28^{\prime \prime} \ldots \ldots \ldots \ldots \ldots \ldots$. . . .

Cardinal Manning-Bishop's purple flushed rosybronze, change to almost pure orange as the flower ages. Large egg-shaped flower. Height $34^{\prime \prime}$

Chestnut-Deep mahogany brown slightly suffused with a purplish bloom, yellow base. Height $26^{\prime \prime}$. .

Copernicus - Deep coffee brown flushed bronzy old rose, olive base. Height $30^{\prime \prime}$. .

Creation-Brilliant orange bronze, changing to bright orange as the flower develops. A glorious new tulip, very large flower on strong stem. Height 28 ".

15.00

Dom Pedro-Coffee brown, petals edged golden brown, inside rich mahogany. Large flower, fragrant. Height $26^{\prime \prime}$

15.00

Fairy (See Panorama)

Feu Ardent - Deep scarlet-crimson, with mahogany suffusion. Large cup shaped flower. Height 28" . .

Godet Parfait - Purplish-violet, white base with blue halo. Very large flower. Height $30^{\prime \prime}$

Goldfinch-Golden chestnut-brown with lilac suffusion through center of petals. Inside mahogany shadings. Height $28^{\prime \prime}$

Gorgeous (See Lucifer)

Great Simson-Deep brown, margined with broad band of golden brown, and overlaid with a purplish bloom, most attractive. Height $26^{\prime \prime}$

Heloise-Purplish-red with old rose shadings, yellow base marked olive green. Height 28".

Indian Chief (Meyerbeer)-Reddish mahogany, edged coppery brown, yellow base. The whole flower overlaid with a purplish flush. Very large flower. Height $32^{\prime \prime}$. Each $\$ \mathbf{0 . 5 0} \ldots \ldots \ldots \ldots \ldots \ldots$

Jaune d'Oeuf (Sunrise)-Deep lemon yellow with flush of ruddy apricot, golden bronze inside. A very beautiful flower. Height 28" (See Illustration).

La Singuliere (Lord Curzon)-Silvery white, margins flushed with deep crimson. Height $26^{\prime \prime} \ldots \ldots \ldots \ldots$. . . .

Le Mogol-Pale mauve, flushed white with white base and blue halo, beautiful. Height $28^{\prime \prime}$.

Louis XIV-Rich, royal purple, flushed golden bronze and margined golden brown. A wonderful large cup shaped flower of stately bearing, and regarded as the most gorgeous tulip in existence. Height $30^{\prime \prime}$. . . . . . (See Illustration)

Lucifer (Gorgeous) - Bright orange terra-cotta, flushed rose with margins of petals edged scarletorange. A brilliant flower on tall stem. Height 26" (See Illustration) 


\section{Breeder Tulips-Continued}

Mabel-Clear cherry blossom pink with white flush, Doz. inside bright cerise with white base. Small but most at tractive flower. Height $28^{\prime \prime}$

$\$ 0.90$

MacMahon (See Turrene)

Marginata (See Orange Perfection)

Marie Louise - Old rose, flushed orange-salmon, edged orange-bronze. A very handsome tulip. Height 24".

Meyerbeer (See Indian Chief)

Mrs. Beecher Stowe-Deep violet blue with white base. Beautiful large well formed flower. Height 28". Each \$0.50.

Orange Beauty (See Prince of Orange)

Orange Perfection (Marginata)-Brilliant apricotorange petals margined golden yellow. A very handsome flower. Height $26^{\prime \prime}$.

Panorama (Fairy)-Deep orange scarlet overlaid with a distinct bluish bloom. Large globular flower on strong stem. Height 22" (See Illustration)...

Perle Royale (Fashion)-White with narrow edge of clear carmine, flower changing to soft rose with age. Large flower on strong stem. Height $26^{\prime \prime}$

Pink Pearl-Deep lilac pink with rosy suffusion and snow white base. A beautiful large egg shaped flower. Height 28" (See Illustration).

Prince Albert-Warm ochre brown, with purplish flush through center of petals, green base. Height $30^{\prime \prime} \mathbf{1 . 0 0}$

Prince of Orange (Orange Beauty, Sunset)-Brilliant orange-scarlet, slight bluish flush and greenishyellow base. Long well formed flower. Height 24 "

Purple Beech-Deep reddish purple with yellowish base. The color reminds of the purple beech, hence the name. Large globular flower. Height $28^{\prime \prime}$.

Rayon d'Or-Bright golden bronze, edged bronzy yellow, center olive. Large finely formed flower with great substance. Height 26". Each \$0.50.

Reve d'Or-Brilliant orange yellow, edged golden yellow and olive green base, flower increasing in beauty as it develops. A most outstanding new kind. Large well formed flower on strong stem. Height 27" Each \$0.50

Roi d'Siam-Dark purplish-violet, lightening toward edges. Fine flowers on strong stem. Height $26^{\prime \prime}$.

Saint James-Chestnut brown, overlaid with a purplish bloom. Very large globular flower. Height $30^{\prime \prime}$

Sans Parielle-Glowing purplish violet, with white base. Height $26^{\prime \prime}$.

Socrates (Violet Queen)-Deep reddish violet, with yellow base turning to white and blue. Large flower on strong stem. Height $28^{\prime \prime}$.

Sun Dance-Orange, flushed bronze with edges of petals light bronze. A beautiful new flower of largest size Strong stem. Height 26"

Sunrise (See Jaune d'Oeuf)

Turrene (MacMahon)-Purplish brown and violet with a broad edge of soft yellow. Very large handsome flower. Height $28^{\prime \prime}$.

Velvet King-Intense deep royal purple, with soft yellowish base. Immense cup shaped flower on very strong stem. Height $28^{\prime \prime} \ldots \ldots \ldots \ldots$ (See Illustration)

Yellow Perfection-Light bronze yellow, edged golden yellow, inside deep bronze. Large fine flower.

Height $26^{\prime \prime} \ldots \ldots \ldots \ldots \ldots \ldots \ldots \ldots \ldots \ldots \ldots \ldots \ldots .75$
NOTE-Add 5 c per doz. for tulips if sent by parcel post.
100

$\$ 7.00$

11.00

8.00

6.50

8.00

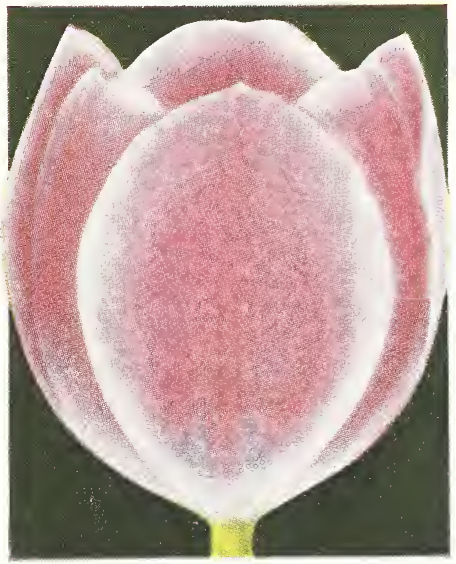

Pink Pearl

\section{Panorama}

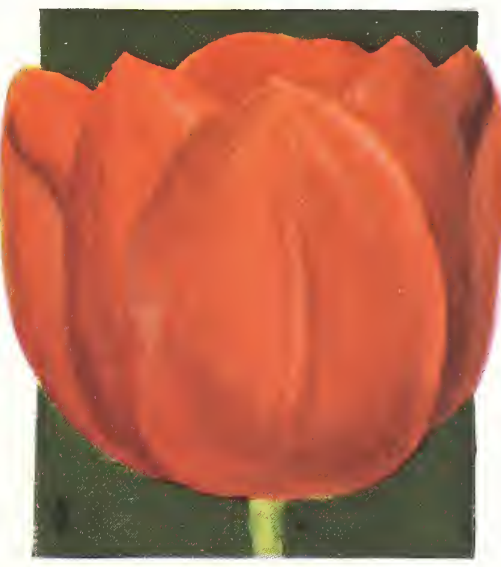

Pink Pearl

H. \& O. SPECIAL MIXTURE OF BREEDER TULIPS

A large variety of these fine tulips. Doz. .\$0.60 $100 \ldots \$ 4.50$ By parcel post or express prepaid. Doz...

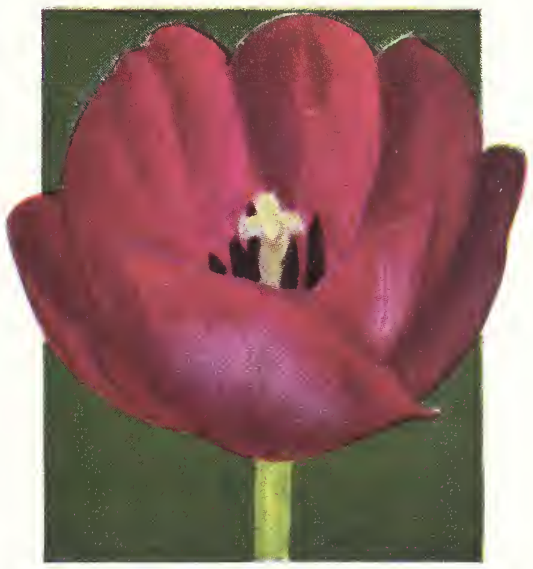

Velvet King 


\section{Cottage and Hybrid Cottage Tulips}

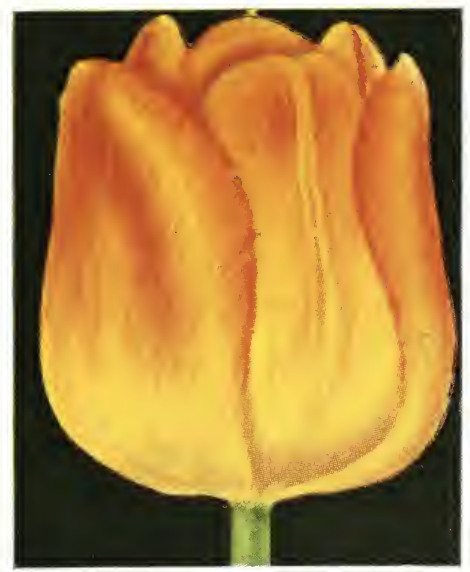

Argo

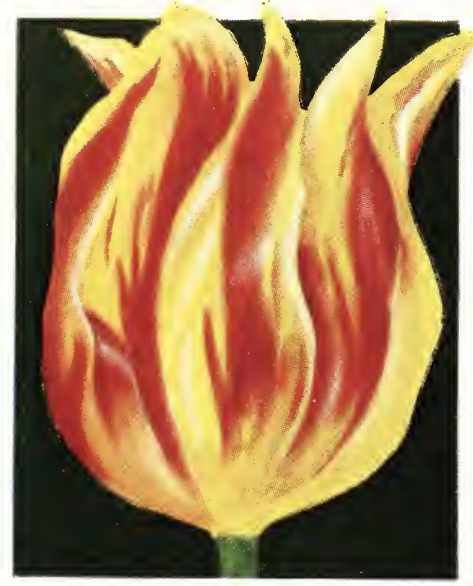

Gala Beauty

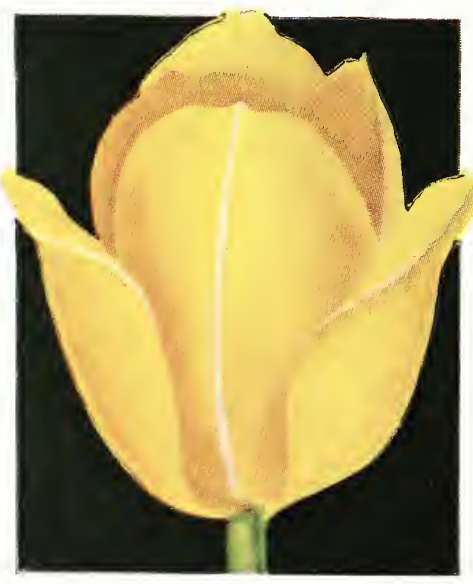

Walter T. Ware
COTTAGE tulips as a class comprise a greater variation in form, and a larger $U$ variety of colors and shades than any other type of tulips. They are hardy and robust with long, slender, stiff stems, some of them gracefully drooping. The flowers are generally long and oval, others with sharp and pointed petals and many open up with gracefully reflexed petals. The Cottage Tulips surpass all others in richness of colors, every imaginable shade can be found among them. Cottage are without question the best cut flower tulips because of their beautiful colorings and their great lasting qualities.

Doz. 100

Ambrosia-Rosy-lilac with wide fawn colored edge, inside brownish buff, green and yellow base. Height $24^{\prime \prime} \ldots \ldots \ldots \ldots \ldots \ldots \ldots$

Argo-Canary yellow, slightly spotted orange. The color deepens to soft golden yellow with large orange spots as the flower ages.

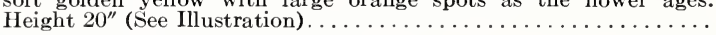

Avis Kennicott-Rich golden yellow with black base and anthers. Very long, large flower. Height $24^{\prime \prime} \ldots \ldots \ldots \ldots \ldots \ldots \ldots \ldots \ldots \ldots$. Bouton d'Or (Golden Beauty)-Rich golden yellow with black anthers. Rather small cup shaped flower. Height $20^{\prime \prime} \ldots \ldots \ldots$.

Buff Beauty-Salmon-orange with buff suffusion, inside orange and yellow. Good sized flower on tall, stiff stem. Height $22^{\prime \prime} \ldots \ldots \ldots \ldots$ Dido-Beautiful large oval flower. Bright salmon-orange inside, outside orange-red with lighter shaded margins. Height $24^{\prime \prime} \ldots \ldots$

Ellen Willmott-Soft canary yellow shading to gold. Beautifully
shaped, large flower. Delightfully fragrant. Height $18^{\prime \prime} . . . . .$. shaped, large flower. Delightfully fragrant. Height $18^{\prime \prime} \ldots \ldots \ldots$
lava-Satiny, soft golden yellow. A handsome medium sized flower that lasts longer on the plant than any other tulip. Height $24^{\prime \prime} \ldots$

Gala Beauty (Columbus)-Rich golden yellow feathered and splashed with crimson. Long pointed petals, fragrant. Height $20^{\prime \prime} \ldots \ldots \ldots 1.25$ (See Illustration)

Gesneriana Spathulata-Rich ruby-crimson with brilliant blue base. Enormous long flower of dazzling brilliancy. Height $24^{\prime \prime} \ldots$

Grenadier-Immense rich orange-scarlet flower, with yellow base. One of the most outstanding late tulips. Flower has excellent form on strong stem. Height $30^{\prime \prime}$...

1.008 .00 1.2510 .00 $.60 \quad 4.50$ .907 .00 $1.50 \quad 12.00$ .756 .00 $2.00 \quad 15.00$ .259 .00

Inglescombe Pink - Rosy pink, flushed salmon, petals bordered with old rose. A most attractive tulip. Height $24^{\prime \prime}$.

Inglescombe Yellow-Glossy golden yellow. Large globular flower. Has the true shape of a Darwin and is often called the Yellow Darwin. Height $18^{\prime \prime}$.

John Ruskin - Salmon-rose, edged with lemon yellow, inside rosy-lilac with yellow base. Large, finely shaped flower on graceful stem. Height $18^{\prime \prime}$

La Mervielle - Brilliant orange-scarlet, slightly flushed rose, yellow base. Very long and large flower. Height $20^{\prime \prime}$.

Maiden's Blush (See Picotee)

Mayflower-Without doubt the largest of all tulips, the color is intensely brilliant orange-scarlet with a glittering black center. The outside is overcast with a greyish-violet sheen. The most brilliant and outstanding flower wherever shown. Height $22^{\prime \prime}$. Each $\$ 3.25,35.00$

Moonlight-Soft, luminous canary yellow. Very large flower with outer petals reflexing at tips. Height $24^{\prime \prime}$

Mrs. Kerrell-Salmon-rose, flushed amber, white center. An excellent tulip and finely formed. Height $20^{\prime \prime} \ldots \ldots \ldots \ldots \ldots \ldots \ldots$

Mrs. Moon-Rich golden yellow, with pointed reflexing petals. A great, large tulip of much substance on strong stem. Fragrant. Height $24^{\prime \prime}$

Orange King - Glowing deep orange, slightly suffused old rose, inside orange-scarlet with yellow center. Globular flower, sweet scented. Height $20^{\prime \prime}$.

Picotee (Maiden's Blush) - Glistening white, margined deep rose, the color suffusing the whole flower as it ages. Pointed, beautifully color suffusing the whole flower as it ages. Pointed, beautifully

reflexing petals. Height $20 \ldots \ldots \ldots \ldots \ldots \ldots \ldots \ldots \ldots \ldots \ldots \ldots \ldots$. color suffusing the whole flower as it ages. Fine large flower with reflexing petals. Height $22^{\prime \prime}$

Rosa Bella-Beautiful shell pink with pale rose edges, white base. An immense beautifully formed flower on stiff stem. Height $26^{\prime \prime}$. .

Sirene-Brilliant, glistening, rose pink, white base. Large, beautiful flower. The petals reflexed and slightly curled. It resembles a great

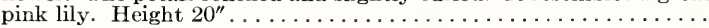

Sir Harry-Soft mauve-rose and yellow base. Large pointed flower. This tulip keeps its color well under all weather conditions. Height

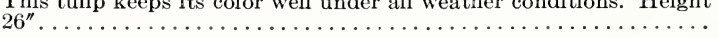

Walter T. Ware-Deep golden yellow. The deepest and richest golden vellow tulip of all. Large globular flower with petals reflexing at tips. Remarkable keeping qualities. Height $20^{\prime \prime}$ (See Illustration) 1.00 NOTE-Add $5 c$ per dozen for tulips if to be sent by parcel post.

\section{H. \& O. SPECIAL MIXTURE OF COTTAGE TULIPS}

This is a special mixture of many fine varieties from the largest grower of Cottage Tulips in Holland................ Doz. \$0.60 $100 \$ \mathbf{4 4 . 5 0}$ By parcel post or express prepaid ..................... $\quad \mathbf{. 6 5} 100 \quad \mathbf{5 . 0 0}$ 


\section{Nere, Rare and Unusual Tulips}

\section{WILD OR NATIVE TULIPS}

THESE are termed Botanical tulips for the reason that they are the original Inative tulips, found in Asia Minor. They are quite unlike the better known tulips in form, color and size. Many of them are small flowered with thin, narrow foliage, others are large and of intense brilliance. They are ideal for naturalizing in the border or rock garden, as they will mutiply and continue to bloom each succeeding season.

Clusiana (The Lady Tulip) — Small creamy white, star shaped flowers, Doz. 100 outside petals flamed cherry red. Height $8^{\prime \prime}-10^{\prime \prime} \ldots \ldots \ldots \ldots \ldots \ldots . \$ 0.75 \$ 66.00$ Eichleri-Fiery searlet with glistening black center, marked with gold. A beautiful native tulip from Turkestan. The flower is of tremendous size and very brilliant. Height $10^{\prime \prime}$

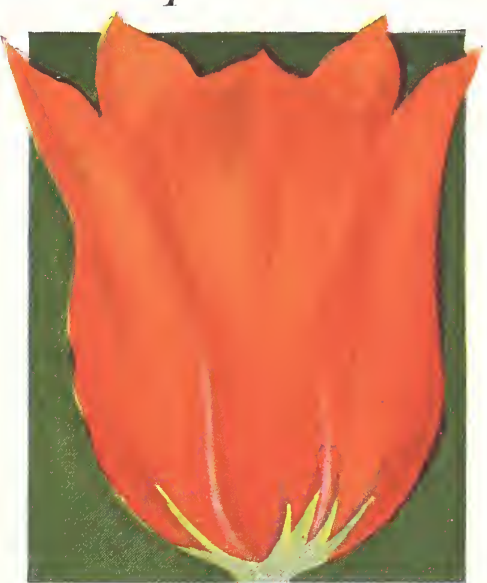

Eichleri (See Wild or Native)

Inga Hume - Inside deep yellow slightly sprayed with red, outsicle red with broad
border of yellow, large black base. Very strong, erect stem. Height 25

Each $\$ 1.00 ;$ Doz. $\$ 10.00$

The Grullemanni is the most recent creation in tulips, and predictions among bulb growers in Holland are that this new race will become the most outstanding class of all when sufficient quantities of bulbs are available.

They possess all the good qualities that can possibly be desired in tulips, size, hardiness, and wonderful lasting qualities, a vigorous constitution and the habit of growth is very robust. The most distinct feature in Grullemanni tulips is their remarkable coloring. They ean very well be termed bi-colored as they show a great variation in the individual flower. The large base or center color is usually deep violet blue or intense black surrounded with a zone of contrasting color. The petals of the large flowers are feathered in contrasting colors with the edges Thually showing a broad band of the thound color. The inside usually shows usualy showing a strong contrast with the outside of the fower, with a marked change and increasing oveliness during the development of the flower which is carried gracefully on a tall slender stem. We list only a few kinds for the reason that they are still very rare.

Annastatia-Inside blush white with reddish flush, outside scarlet with faint white feathering, large dark purplish base. Very large

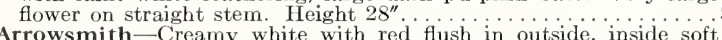

Each Doz

creamy white with large blue base, strong stem. Height $28^{\prime \prime} \ldots . .$.

Chiaroscure-Blush white, heavily red in and outside, borders of petals with broad yellow band, sharply lined red, large blue center. Height $24^{\prime \prime}$

Exotic-Inside primrose yellow, outside ereamy white with reddish suffusion, large greenish black base. Globular flower on strong stem. Height $27^{\prime \prime}$

Grisilde-Inside of petals ereamy white changing to yellow toward center, outside white with red feathering in center of petals, large greenish black base. Large oblong flower of wonderful substance. Height $26^{\prime \prime}$.

\section{TRIUMPH TULIPS}

These are a most interesting new race of tulips, the result of successful crossing of the so termed Single Early with the Darwin tulips. Among these will be found some very unusual colors and some that are unique.

They are very robust in growth, mostly with thick, firm stems, and with wonderful keeping qualities. Blooming time is about ten days earlier than Darwins and the height of most kinds may be called medium, on an average of twelve to eighteen height of

Triumph tulips are most desirable for planting where earlier flowers are desired, or where a more extended period of bloom is wanted in the garden, planted with the later blooming kinds a longer season is assured.

We offer here a few of the very best sorts.

Astoria- Doz. 100 Astoria Buffalo - Dull mauve, inside bright purple, fine large flower. Height

.

Georgia-Royal purple, bordered earmine red. Height $18^{\prime \prime} \ldots . . . .$.
Hugo Stinnes-Bright cochineal red, deep yellow base. Large well

Hugo Stinnes-Bright eochineal red, deep yellow base. Large well $\mathbf{1 2 5}$

Lord Carnavan-Rose pink with white stripes, white base, beautiful large conical flower. Height $22^{\prime \prime}$. (See illustration) ........... 1.00

Mississippi-Glowing purplish-red, bluish white base. Large oval flower. Height $18^{\prime \prime}$

Ohio-Soft carmine red with violet shadings, white base. Height $2 s^{\prime \prime} 1.00$ Professor Tendelo - Deep amaranth red flushed violet with broad edge of yellow, bluish white base. Height 22"

Thucana-Bright orange red, a brilliant large well formed flower.

Height $18^{\prime \prime} \ldots \ldots \ldots \ldots \ldots \ldots \ldots \ldots \ldots \ldots \ldots \ldots \ldots \ldots \ldots \ldots \ldots \ldots$
NOTE-Add $5 \mathrm{c}$ per dozen for tulips if to be sent by parcel post
Mimosa - Inside deep primrose yellow, outside blush white with red shadings, large intense black base with yellow border. Enormous oblong flower. Height $28^{\prime \prime}$. Each \$1.00; Doz.\$10.00

Papine - Inside white slightly flushed red, outside reddish with broad white edges on petals, large brownish black base Height $27^{\prime \prime}$.... Each $\$ \mathbf{1 . 0 0} ;$ Doz. $\$ \mathbf{1 0 . 0 0}$

Serge Batourini-Inside white, faintly flushed red, outside blush white with center of petals heavily feathered red, dark blue base with broad yellow zone. Long flower on sturdy stem. Height $26^{\prime \prime}$ Each \$1.00; Doz. \$10.00

Triumphalis - Inside blush white, slightly flushed with red outside petals with broad center with broad white zone. Enorme center with broad white zone. Enormous egg shaped flower on strong stem. Height

To introduce these wonderful and rare tulips we will supply the 10 varieties, one bulb of each for $\$ \mathbf{\$ 7 0}$.

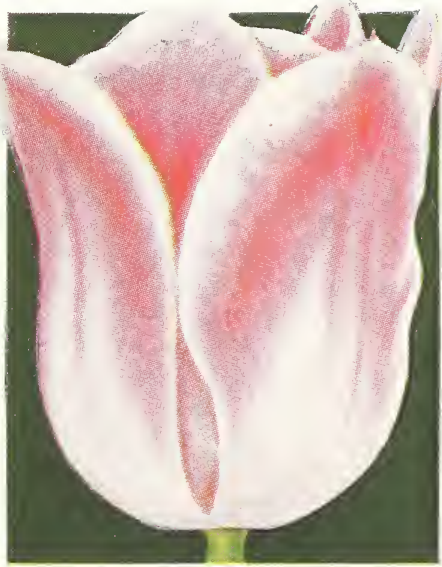

Lord Carnavan, Triumph Tulip markings in crimson, large purplish blue 


\section{Early Flowering Tulips}

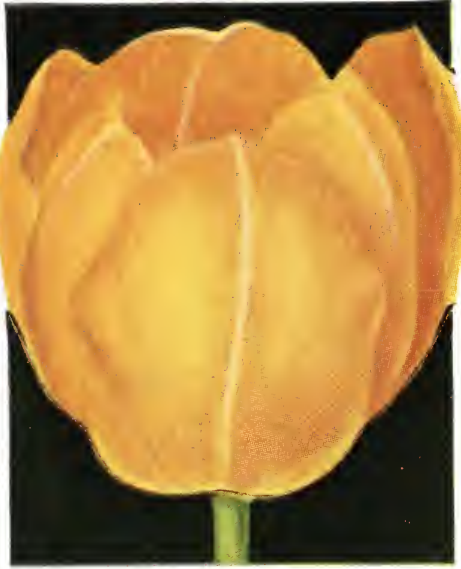

General DeWet

\section{PARROT TULIPS}

These curious flowers are both brilliant and showy. The very large flowers are fringed and lacinated in a most fantastic way. They should be planted in the border way. They should be planted in the border ing and curling habit of growth.

Cramoise Brilliant-Deep erimson and scarlet ...........Doz. 65c; $100 \$ \mathbf{4 . 5 0}$

Fantasy - Beautiful rosy-salmon with straight, strong upright stem, unlike other Parrot tulips in this respect. Fantasy is a very wonderful and sensational new kind, very searce. Height 18".

Each 50c; Doz. \$5.00

Gemma-White with a flush of soft rose pink, dwarf in growth but strong and

Lutea Major - Lemon yellow with deeper stripes........... Doz.65c; $100 \$ 4.50$

Perfecta-Red and yellow with striped shadings. . . . . . . . Doz. 65c; $100 \$ 4.50$

Parrot Tulip Mixture - Many fine kinds Doz. 50c; $100 \$ 4.00$

NO'TE-Add $5 c$ per dozen for tulips if to be sent by parcel post.

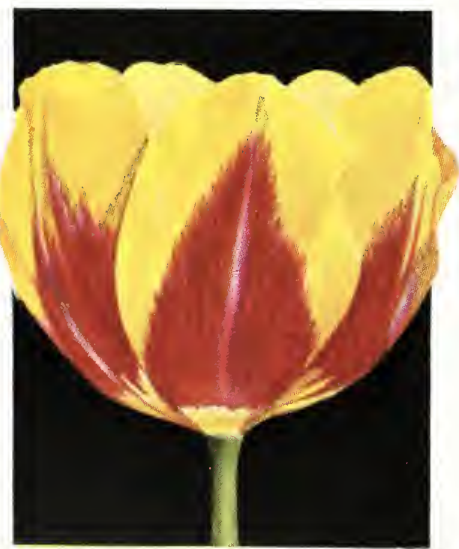

Kaiserkroon

THESE are the earliest tulips to bloom in the garden, and the easiest to bring into bloom indoors. Some may be flowered by the end of December if given proper attention. This class contains every hue and color, from the purest snow white to the deepest crimson.

Outdoor Planting-Any good garden soil prepared by spading to a depth of 8 to 10 inches is suitable. Plant the bulbs five inches apart for mass effect, and about five inches deep. The bulbs should all be planted at an equal depth where it is desired to have them bloom equally. Firm the soil well about the bulbs, and cover the beds with leaves or straw before severe cold weather sets in. As soon as snow and ice will allow, remove the covering.

House Culture - Plant six or more bulbs in a pot, set away in a cool, dark place (a good cool cellar is ideal) for a period of six to ten weeks to allow roots to develop. When quite a number of roots show through upon tipping out of pot, they may then be brought into the warm room and light, to bloom.

The approximate height in inches is indicated by a figure following the variety name.

\section{SINGLE EARLY FLOWERING TULIPS}

\section{RED SHADES}

Artus, 8-Bright scarlet $\$ 0.50 \$ 4.00$

Auc Von Thol, 6-Vermillion-scarlet, very early indoor flowering . .

Prince of Austria, 13-Orange scarlet, large fine flower .

Vermillion Brilliant, 12 - Brilliant vermillion-scarlet, yellow base early

\section{PINK SHADES}

Cottage Maid, 9-Rosy pink, white suffusion

La Reve (Hobbema), 11 - Bronzy old rose, edged pale lilac-rose. Large flower on strong stem

Pink Beauty, 12-Very large, deep, cherry-rose flower with white stripe, through petals. The best pink for outdoor planting.......

Rose Luisante, 12-Brilliant deep rose-pink, fine large flower. Excellent for outdoor planting

\section{YELLOW AND ORANGE SHADES}

Chrysolora, 10-Clear golden yellow

Gen'l De Wet, 16-Deep, brilliant golden-orange. Very large flower and a wonderful tulip

$$
\text { (See Illustration) }
$$

King of the Yellows, 12-Deep golden yellow.

Yellow Prince, 12-Golden yellow with a slight feathering of red. Fine for indoor culture.

\section{WHITE}

Lady Boreel, 10-Large, glistening snow white White Hawk, 12-Fine early, pure white.

\section{STRIPED AND VARIEGATED}

Cardinal Rampollo, 10-Deep orange bordered yellow .

Carnival Prince, 12-A sensational new kind, golden yellow, heavil flamed carmine. Large fine flower. Each \$0.30 ...............

Duchess d'Parma, 12 - Deep orange-maroon, bordered deep yellow. Very brilliant in beds.
Joost von den Vondel, 11 - Deep cherry red, blotched and striped white, large flowers . . . . . . . . . . . . . . . . . . . . . . . . . . Kaiserkroon, 14-Bright crimson searlet, heavily edged deep golden yellow. Very large flowers.... (See Illustration)

.65555 .00

.806 .00

$.70 \quad 5.50$

.907 .00

1.5010 .00

.806 .00

$.75 \quad 5.50$

1.2510 .00

.806 .00

.70 5.00

.806 .00

$.70 \quad 5.00$

1.007 .50

$3.00 \quad 22.50$

5.00

5.00

$\mathbf{7 . 5 0}$

H. \& O. SPECIAL MIX'TURE OF SINGLE EARLY TULIPS

Iany fine and unusual kinds will be found in this mixture . . . . . . .45 3.25

NOTE-Add $5 c$ per dozen for tulips if to be sent by parcel post.

\section{DOUBLE FLOWERED TULIPS}

These fine large peony-like flowers deserve a greater popularity than is being accorded them. They come into bloom long before the late blooming kinds and make a brilliant display in the garden or border. They may be grown indoors very satisfactorily with cultural care the same as for the early single kinds.

Crown d'Or, $10-$ Brilliant reddish orange

Doz. 100

$\$ 0.90 \quad \$ 7.00$

Electra, $10-$ Deep violet with rose and orange shadings

E1 Toreador, 8- Orange scarlet, bordered bright yellow

Imperator Rubrorum, 10-Large deep scarlet. Early

Mr. Van der Hoof, 9-Pure golden yellow

Murillo, 8-Light rosy pink, fine large flower

Peach Blossom, 9-Beautiful, large rose pink flower

Rubra Maxima, 11-Intense deep scarlet. Large peony-like flower

Schoonaard, 12-The largest pure white double tulip. Very fine.

Tea Rose, 10-Light canary yellow suffused with apricot.

Titian, 8-Deep brownish red, edged bright golden yellow.

NO'TE-Add 5c per dozen for tulips if sent by parcel post.

\section{SUPERFINE MIXED DOUBLE TULIPS}

A large variety of fine kinds.

By parcel post or express prepaid.
1.2510 .00

907.00

$.70 \quad 5.50$

$.60 \quad 4.50$

.806 .00

6.00

6.00

4.50

4.50

年

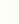




\section{Unusual Tulips-Continued}

\section{CLUSTER FLOWERED TULIPS}

This is a new type in tulips. Instead of one flower on a stem these develop a cluster of four, five and six good sized flowers which are all in bloom at same time. Doz. 100 Monsieur Mottet -20 . Ivory white flowers ... \$1.00 \$7.00 Madame Mottet-22. Purplish rose flowers …... 1.50 12.00

\section{REMBRANDT TULIPS}

These are like Darwins in size and form. They are the so-called broken colors that appear as sports from the Darwins. Flower that revert back partly to the parent flowers, striped and blotehed in a great variety of colorations. They were christened Rembrandts for the reason that they resemble the tulip flowers seen in old Duteh paintings. Doz. 100 Well mixed in many unique colors .........\$1.00 \$7.00

\section{BIZARDS AND BI-BLOOMS}

These are tulips that originate in the hybridization of Breeder Tulips, which results in feathered or flamed markings. They present many beautifully marked flowers in unusual coloring The flowers are of mediun size on stiff stems averaging 18 to 22 inches tall. Doz. 100 Bizards-Feathered and flamed brown sharles on yellow around $\$ \mathbf{\$ 0 . 7 5} \$ \mathbf{\$ 6 . 0 0}$ Rose Bi-Blooms-Feathered and flowered rose on white ground .................. $75 \quad 6.00$

Violet Bi-Blooms - Feathered and flowered violet shades on white ground . NOTE-Add $5 \mathrm{c}$ per dozen for tulips if to be sent by parcel post.

\section{Tulip Collections}

$\mathrm{O}$

UR Bulb Collections continue growing more popular each year. We find that our customers who purchase these collections are pleased with them and buy again each succeeding year. The main reason for this, we believe, is that we put into these collections only the very best kinds and finest quality bulbs, and also because of a considerable saving in cost. While we try to make each collection alike, we find that some varieties do not sell as readily as others, due to price, etc., and in order to equalize our stocks we include many of the higher priced kinds in these collections. We make up all the collections we offer ourselves, and know that each one is just as represented. Every collection offered contains extra value and we feel confident will please the most exacting.

\section{DARWIN TULIP COLLECTIONS}

These have become very popular as we put into these collections only the choicer kinds. We have large stocks of all varieties listed, some of which do not sell as readily as others, and to reduce stock more evenly we use many of the higher priced kinds in making up these collections. Purchasers are assured of getting a very fine selection, and extra value.

DARWIN TULIP COLLEGTION-No. D6 Contains sixty bulbs, 4 each of 15 different kinds for $\$ \mathbf{2 . 5 0}$. By parcel post prepaid, \$2.75

DARWIN TULIP COLLEGTION-No. D7

Contains one hundred and twenty bulbs. 6 each of 20 different kinds for $\$ \mathbf{5 . 0 0}$. By parcel post or express prepaid $\mathbf{\$ 5 . 5 0}$.

DARWIN TULIP GOLLEGTION-No. D8 Contains ninety bulbs, 3 bulbs each of 30 different kinds for $\$ \mathbf{3 . 7 5}$. By parcel post prepaid, \$4.10.

DARWIN TULIP COLLECTION-No. D9 Contains one hundred and eighty bulbs, 6 bulbs each of 30 different kinds for $\$ 7.25$. By parcel post or express prepaid, $\$ \mathbf{7 7 . 9 0}$

\section{COLLECTIONS OF BREEDER TULIPS Collection B1}

Contains 48 bulbs, four of each in twelve choice and distinct kinds for $\$ 2.50$. By parcel post prepaid $\$ \mathbf{2 . 7 5}$.

\section{Collection B2}

Contains 100 bulbs, five of each in twenty varities. This collection comprises every color and shade in Breeder tulips. $\mathbf{\$ 5 . 0 0}$ By parcel post prepaid, $\mathbf{\$ 5 . 5 0}$.

\section{COTTAGE TULIP COLLECTIONS}

\section{No. C12}

Contains thirty-six bulbs, 3 each of twelve distinet and different kinds, for \$2.00. By parcel post prepaid $\$ \mathbf{2 . 1 5}$.

\section{GOTTAGE TULIP COLLEGTION No. C13}

Contains seventy-two bulbs, 6 each of 12 distinct and different kinds, for \$3.75. By parcel post prepaid $\mathbf{\$ 4 . 0 0}$.

\section{PROPER PLANTING DEPTH FOR DIFFERENT BULBS}

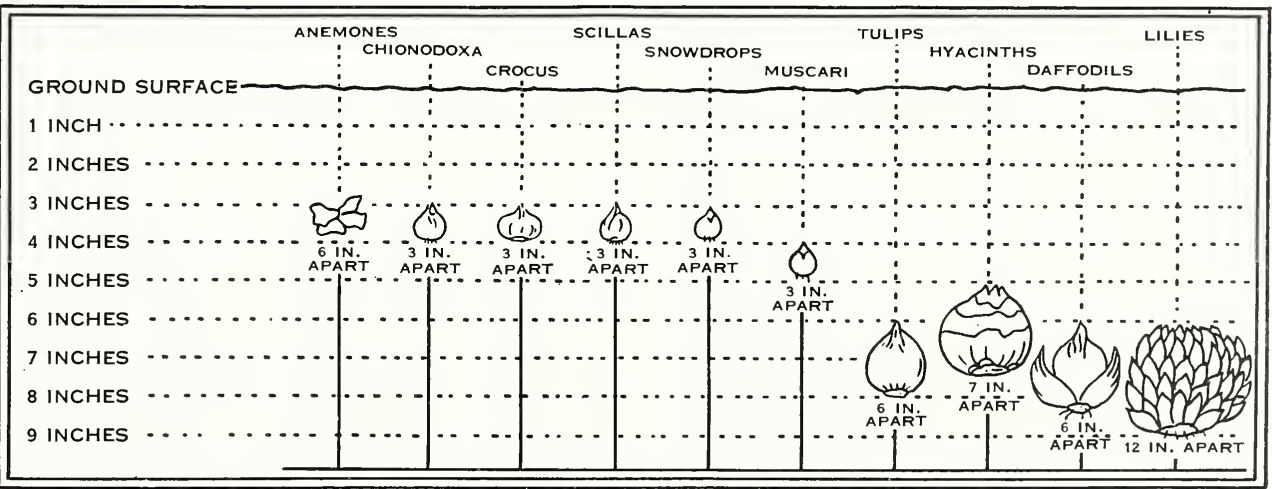




\section{Daffodils-Jonquils-Narcissi}

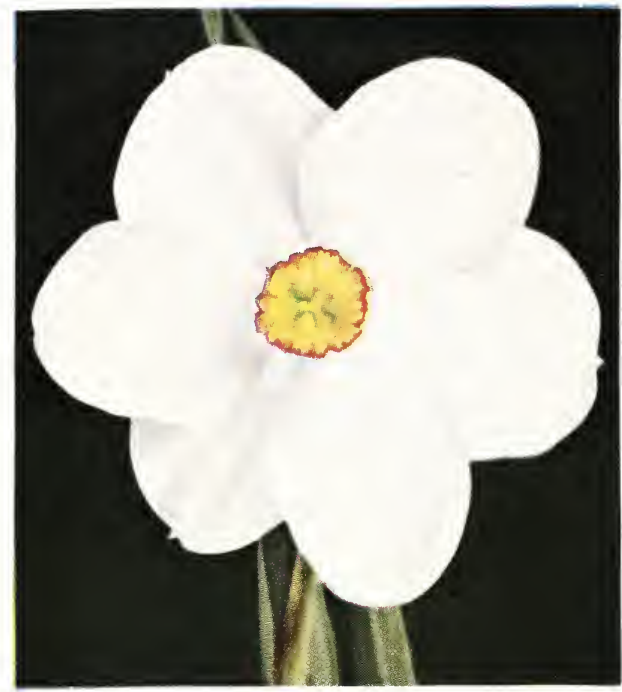

Eagle

\section{DIFFERENT TYPES OF NARCISSI}

Barri-The cup or crown measures less than one-third the length of the perianth segments or petals.

Camparnils - Smaller flowers in clusters of three to six. Incomparabilis - Cup or crown measuring one-third to nearly equal the length of the perianth segments.

Leedsi-Comprises all the low or short cupped crowns with white or silvery perianth, the crown white or slightly colored.

Poetaz - Flowers resulting from crosses between the Poeticus and Polyanthus Nareissus. Flowers in clusters, perianth petals fleshy.

Poeticus - Snowy white perianth with bright, short flattened crown or eye.

Trumpet - Trumpet or crown as long or longer than the perianth.

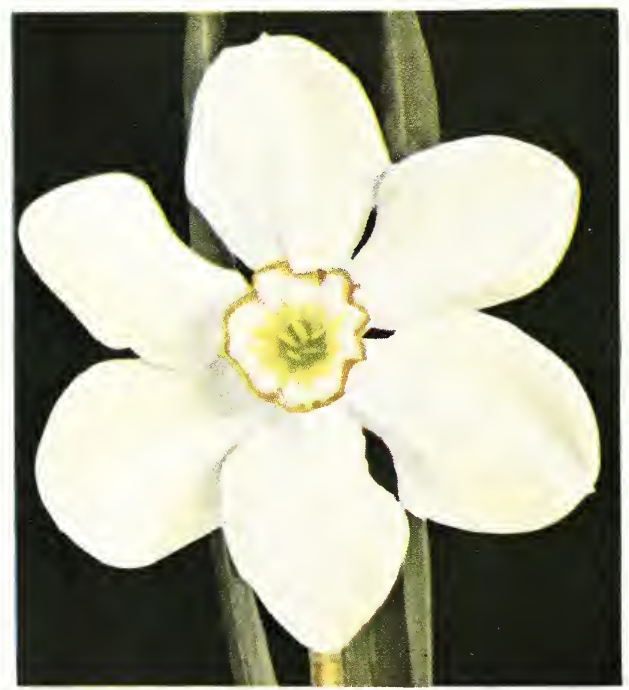

Evangeline
FITHER of these names applied to any individual kind in this group is perfectly correct, though it has become a somewhat established custom to term the large trumpet types as "Daffodils," and all the short cupped and eluster flowered types as Narcissus. In many sections the latter are more popularly known as Jonquils, but actually "Jonquils" form a rather small group, producing small flowers in clusters.

The embargo forbidding the importation of Daffodils a few years ago has resulted very favorably for America in that finer and better bulbs produced in this country are now available. Before the exclusion act became effective a few of the leading Holland Narcissus growers brought in their stocks of the choicest varieties, which, while in some instances are not available in large quantities, have added some exquisite new kinds that were not procurable before.

The bulbs which are being produced in America by these expert growers have proven superior to those formerly imported.

Daffodils are among the first flowers that greet us in the spring. Nothing is lovelier or more welcome than the first glimpse of a cluster of these, with their cheerful brightness displayed before the winter snows are quite forgotten, and before many other flowers have started to show signs of activity.

Narcissi prefer a partially shaded location, but will thrive and increase in most any situation. They will continue to increase and bloom from year to year.

They may be grown indoors quite successfully, treating them the same as early tulips, planting them in pots, but should be given more time for root development before being brought into the light. The proper time for this is when a considerable network of the white roots show through when tipped out of pot.

Our Narcissi come from the largest and most noted grower in this country. In the following list we offer a complete list of the choicest and most desirable kinds. The bulbs are all of the largest size and in perfect condition.

Argent (Semi-double) - Large, creamy white flower, with high yellow center. 15c each, \$1.50 per doz., \$12.00 per 100 .

Barri Conspicuus (Barri) - Soft yellow perianth, short cup edged, bright orange-scarlet. $10 \mathrm{c}$ each, $\$ 1.00$ per doz., $\$ 7.50$ per 100 .

Bath Flame (Barri) - Bright primrose perianth, broad yellow cup, edged deep orange-red, superb large flower. 50c each, $\$ 5.00$ per doz.

Beppy (Trumpet) - A beautiful Bi-color. Large broad, deep yellow trumpet, finely frilled with pure white perianth. 25c each, $\$ 1.50$ per doz., $\$ 20.00$ per 100 . 


\section{Daffodils-Jonquils-Narcissi-Continued}

Bernardino (Incomparabilis) - Wonderful large flower, large creamy white perianth, very large frilled and fluted primrose cup with orange and apricot tinted edges. 25c each, $\$ 2.50$ per doz., \$20.00 per 100.

Camparnil Gigantheus (Comparnil)-Deep golden yellow clusters of four to six large flowers. The true sweet scented Jonquil. 15c each, \$1.60 per doz., \$12.00 per 100.

Camparnil Rugulosus Flo. Pleno (Camparnil)-Rich, deep golden yellow flowers in clusters of four to six. The double sweet scented Jonquil. 15c each, $\$ 1.60$ per doz., \$12.00 per 100 .

Camparnil Orange Queen (Camparnil)-Identical with Camp. Gigantheus except in color, which is intense deep golden yellow. $15 \mathrm{c}$ each, $\$ 1.60$ per doz., $\$ 12.00$ per 100

Cleopatra (Trumpet) - Very broad imbricated yellow perianth, long deep golden yellow trumpet. Larger but similar to Emperor. 50c each, \$5.00 per doz., \$40.00 per 100 .

Dante (Poeticus) - Pure white perianth, cup margined bright red, earliest of all Poeticus Narcissi. 15c each, $\$ 1.50$ per doz., \$11.00 per 100 .

Eagle (Poeticus) - Very large, broad petaled, snow white perianth, with intensely brilliant orange-scarlet cup. Early flowering and without question the finest of the Poeticu group. 30c each, $\$ 3.00$ per doz., $\$ 22.50$ per 100 .

$$
\text { (See Illustration Page 12) }
$$

Emperor (Trumpet)-Deep primrose yellow perianth, large, rich yellow trumpet. Very large flower and one of the very best of the large trumpets. 20c each, \$2.00 per doz. $\mathbf{\$ 1 5 . 0 0}$ per 100 .

Evangeline (Leedsi) - Very large white perianth, with prettily frilled lemon-yellow cup. Tall, graceful and very refined flower. 15c each, $\$ 1.50$ per doz., $\$ 11.00$ per 100 .

$$
\text { (See Illustration Page 12) }
$$

Firebrand (Barri) - Perianth creamy white shading to yellow at base, cup intense fiery red. A most brilliant flower. 15c each, $\$ 1.50$ per doz., $\$ 11.00$ per 100 .

$$
\text { (See Illustration) }
$$

Glory of Sassenheim (Trumpet) - A glorious bi-color, broad, creamy white perianth, large, deep canary-yellow trumpet. $20 \mathrm{c}$ each, $\$ 2.00$ per doz., $\$ 15.00$ per 100 .

Golden Beauty (Trumpet) - Soft primrose-yellow perianth, brilliant orange-yellow trumpet, large flower, late blooming. The color in this flower is the deepest of all Narcissus. 20c The color in this flower is the deepest
each, $\$ 2.00$ per doz. $\$ 15.00$ per 100 . (See Illustration)

Juliet (Poeticus) - Larger and stronger than Poeticus Ornatus, which it otherwise resembles. 15c each, $\$ 1.50$ per doz. $\$ 10.00$ per 100 .

Jonquil, Single (Camparnil)-Bright golden yellow flowers in clusters. This is the old original Jonquil. 10c each, \$1.10 per doz., $\$ 8.00$ per 100 .

Jonquil, Double (Camparnil Fl. Pleno)-This is the double flowered type of the preceeding variety. 12c each, $\$ 1.25$ per doz., \$9.00 per 100

King Alfred (Trumpet)-Clear, deep, rich golden yellow of uniform color, large flower. Beautiful, large wide trumpet, deeply frilled and recurving. 25c each, $\$ 2.50$ per doz. $\$ 20.00$ per 100.

$$
\text { (See Illustration Page 14) }
$$

Laureate (Poeticus) - Very large pure white perianth, large yellow cup with brilliant scarlet rim. $25 \mathrm{c}$ each, $\$ 2.50$ per

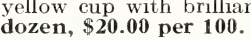

Laurens Koster (Poetaz)-Broad, creamy white perianth petals, with deep orange cup in clusters, delicately tragrant. $10 \mathrm{c}$ each, $\$ 1.00$ per doz., $\$ 7.50$ per 100

Lucifer (Incomparabilis)-Large, rounded silvery-white perianth. Long fluted yellow cup with bright orange-red rim. $15 \mathrm{c}$ each, $\$ 1.60$ per doz., $\$ 12.00$ per 100

Martha (Trumpet) - Beautiful, silvery-white perianth, large, rich yellow trumpet. A strong, robust bi-color. 15c each, rich yellow trumpet. A strong,
$\$ 1.50$ per doz., $\$ 12.00$ per 100 .

Masterpiece (Barri)-Broad, imbricated white perianth, with large, widely expanded and fluted cup of intense orange and crimson. A Narcissus of great substance. 25c each, \$2.50 per doz., $\$ 20.00$ per 100 .

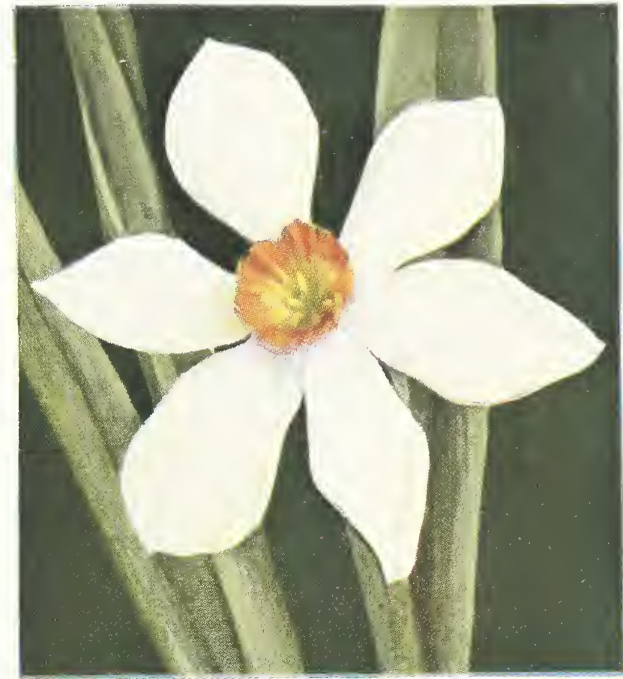

Firebrand

Minister Talma (Trumpet) - Perianth and trumpet deep uniform golden yellow. Very large, wide open trumpet, very distinct. 20c each, \$2.00 per doz., \$15.00 per 100 .

Olympia (Trumpet) - A giant trumpet daffodil. Very robust, perianth and trumpet golden yellow. 35c each, $\$ 3.50$ per doz., \$25.00 per 100 .

Orange Cup (Poetaz) - Primrose yellow perianth, with brilliant gold and scarlet-orange cup, nicely frilled. Large clusters of sweetly fragrant flowers. 20c each, \$2.00 per doz., \$15.00 per 100 .

Poeticus Ornatus (Poeticus) - Perianth purest snow white oeticus Ornatus (Poeticus) - Perianth purest snow white, Pheasant's Eye. 10c each, \$1.00 per doz., \$7.00 per 100.

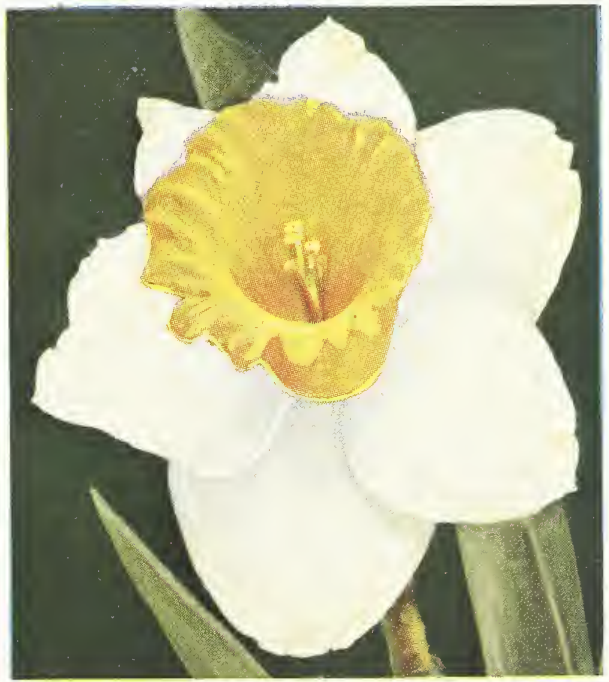

Golden Beauty 


\section{Daffodils-Jonquils-Narcissi-Continued}

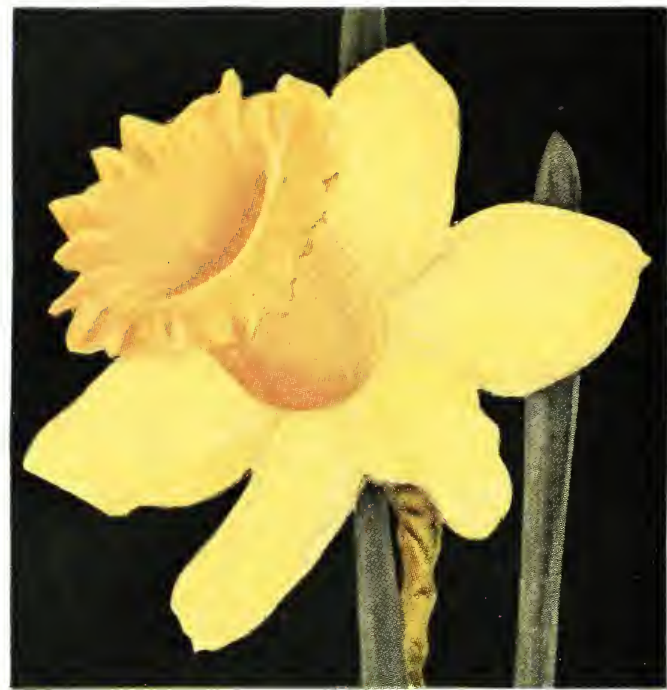

King Alfred

Pres. Roosevelt (Trumpet) - A beautiful daffodil with white perianth and soft yellow trumpet. An exquisite flower. $30 \mathrm{c}$ each, $\$ 3.00$ per doz., $\$ 22.50$ per 100 .

Queen of England (Poeticus)-Broad, snow white perianth. Brilliant orange cup with beautifully frilled, scarlet rim. 15 c each, $\$ 1.50$ per doz., $\$ 11.00$ per 100.

Red Chief (Barri)-Broad petaled, glistening white perianth, wide, deep yellow cup with bright crimson margins beautifully frilled. 20c each, $\$ 2.00$ per dozen, $\$ 15.00$ per 100 .

Sir Watkin (Incomparabilis)-Primrose-yellow perianth, orange-yellow cup. Very large flower, grows very tall. One of the very best and most popular Narcissus. 12c each $\$ 1.25$ per doz., $\$ 10.00$ per 100 .

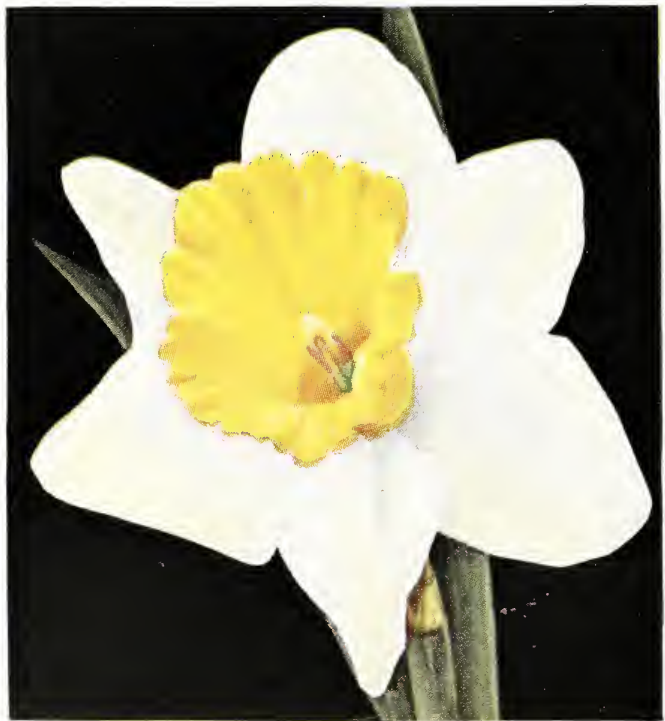

Spring Glory
Spring Glory (Trumpet) - A magnificent and beautiful bicolor. Very large, pure white, imbricated perianth, great open golden-yellow trumpet, reflexing at the brim. Delightfully fragrant. 20c each, \$2.00 per doz., \$16.00 per 100 (See Illustration)

Sulphur Beauty (Trumpet)-Very large, imbricated white perianth. Broad and large pale sulphur trumpet, with finely fluted, reflexed rim. 20c each, $\$ 2.00$ per doz., \$15.00 per 100.

Thalia - This is a very distinct and unique departure among Narcissi. Three or four pure white flowers which resemble Orchids on one stem. Known as the Orchid Narcissi. Largest bulbs $\$ 1.40$ each, $\$ 15.00$ per doz.

Tresserve (Trumpet)-Mammoth canary-yellow, imbricated perianth. Trumpet soft golden yellow, very large, broad and open with recurved brim. A very robust, free flowering Narcissus of enormous size 30c each, \$3.00 per doz. $\$ 22.50$ per 100 .

Triumph (Poetaz) - Three to five large flowers in cluster, very broad pure white perianth and large deep yellow cup. 15c each, \$1.50 per doz., \$12.00 per 100 .

Van Waveren's Giant (Trumpet) - A giant among Daffodils. Perianth pale primrose. Strongly imbricated, massive, golden yellow trumpet with very broad brim. $45 \mathrm{c}$ each, $\$ 5.00$ per doz.

Von Zion (Double Trumpet)-Pure, deep golden yellow, large expanded double trumpet. The old fashioned double Daffodil 15 c each, $\$ 1.50$ per doz., $\$ 11.00$ per 100.

Victoria (Trumpet)-Broad, creamy-white perianth with closely overlapping petals. Bright golden yellow trumpet with wide frilled brim. Best for indoor culture. 15c each. $\$ 1.50$ per doz., $\$ 11.00$ per 100 .

White Lady (Leedsi)-Broad, white perianth. Small beautifully crinkled pale canary cup. Very free flowering variety. fully erinkled pale canary cup. Very ree

Will Scarlet (Incomparabilis)-Reflexing, creamy-white perianth. Very broad, open, fiery orange-scarlet cup, elegantly frilled. Late blooming, best for outdoor culture. 20c each, $\$ 2.00$ per doz., $\$ 15.00$ per 100

\section{POLYANTHUS NARCISSI}

These are best suited to indoor culture and are very satisfactorily grown in either pots or in the bulb bowl in water. If planted outdoors they should be heavily covered.

Our bulbs are American grown and we consider them superior in every way to those formerly imported from France.

Gloriosa-Very free and early flowering. Flowers in large clusters and similar to the Chinese Lily. Large bulbs 15c each, $\$ 1.50$ per doz.

Grand Soleil d'Or-Large clusters of deep golden yellow flowers, strongly fragrant. Large bulbs 35c each, \$3.00 per doz.

Paper-White (The French Narcissus) Pure White. Very desirable for growing in bowls of water and pebbles. Large bulbs 10c each, $\$ 1.00$ per doz.

NOTE-Add 15c per dozen for all Narcissi if to be sent by parcel post. 


\section{Dutch Hyacinths}

CROWING Hyacinths indoors is a very simple matter indeed, and the pleasure derived in watching the development of the bright $\checkmark$ cheery, sweetly perfumed flowers during the winter days is ample reward for the slight effort.

INDOOR CULTURE IN POTS-Use ordinary good soil with a little sand to make it more porous. Place a piece of broken crock over the hole in bottom of pot so as to insure free drainage. Fill in with enough of the soil so that the top of the bulb or bulbs is a little below the level of the top. Cover the top of bulbs with soil and firm so as to have at least a half inch below rim. Use 4 or 5 -inch pots for the larger bulbs when planting them singly. A number of the smaller bulbs planted in larger shallow pots is very satisfactory. After being potted they should be watered thoroughly and then placed in a cool, dark place (preferably a vegetable cellar) for a period of six to ten weeks. This will induce root growth.

To ascertain the right time to bring them out of the dark, tip the pot upside down, tapping lightly so as to lift pot off soil. If several of the white roots show, it is then safe to bring them into the light

Hyacinths may also be grown in glasses of water. The bulb should be placed so that the bottom just touches the water and enough water added occasionally to keep it at the proper level. Hyacinths grown in water should also be kept dark until roots 3 to 4 inche are developed. Better results are obtained by growing them as cool as possible

OUTDOOR CULTURE-Plant the bulbs uniformly about 6 inches deep. Doing so carefully will insure them blooming evenly When planting a larger bed, the best plan is to remove about 4 inches of soil, firm bulbs in place about 6 inches apart each way, and cover them firmly.

\section{BLUE AND VIOLE'T SHADES}

Bismarck - Sky blue. Early

Grand Maitre-Deep porcelain blue

King of the Blues-Intense violet blue

Lord Derby-Porcelain blue

Queen of the Blues - Light blue

Queen of Violets-Rich violet
PINK RED AND ROSE SHADES

Gertrude-Rose pink. Fine variety

La Victoire-Brilliant rosy pink

Marconi-Beautiful deep rosy pink

Queen of the Pinks-Delicate silvery

$$
\text { pink }
$$

Roi des Belges-Bright Scarlet

\section{WHITE}

La Grandesse-Pure white. Large truss L'Innocense-Tall, fine spike

Queen of Whites-Finest white. Late

White Lady - Large compact spike

City of Haarlem-Pure yellow. Large spike

PRICES OF EXHIBITION TOP SIZE HYACINTHS-These are the largest and very choicest bulbs grown in Holland PRICES OF $\{$ and will produce immense flower spikes. Price 20c each, \$2.00 per doz.

HYACINTHS TFIRST SIZE HYACINTHS-This size bulb produces large fine flower spikes. Price 15c each, $\$ 1.50$ per doz. UNNAMED HYACINTHS IN COLORS - These are first size bulbs of varieties that are not grown under name. They will produce very choice flowers. They are equally good for indoor culture or planting outdoors.

Red or Rose Shades, Pink Shades, Dark Blue Shades, Light Blue Shades, Mauve and Violet Shades, White-Yellow Price 10c each, $\$ 1.00$ per doz.-Add $15 \mathrm{c}$ if to be sent by parcel post.

MIXED HYACINTHS-These are first size bulbs that will produce fine spikes of flowers. This mixture contains a large variety. Price 8c each, 90c per doz. Add 15c per doz. if to be sent by parcel post.

\section{FRENCH ROMAN HYACINTHS}

Beautiful, pure white flowers, Large bulbs $15 \mathrm{c}$ each, $\$ 1.50$ per dozen. Postage 10c per dozen extra.

Hyacinth Collections Many of our customers have requested collections of Hyacinths, leaving the selection to us, and yacinth Collections we offer the following: Hyacinth Collection No. H1 - Twelve exhibition size Hyacinths in twelve different varieties and colors, tor \$1.80. By parcel post prepaid, \$2.00.

Hyacinth Collection No. H2-Twelve first size Hyacinths in twelve different varieties and colors, for \$1.35. By parcel post prepaid, $\$ \mathbf{1 . 5 0}$.

\section{FREESIAS}

These dainty, spicy, sweet-scented blossoms can easily be had in bloom at Christmas if planted early. They are only suited for pot culture as they are not hardy. Plant a number of bulbs to the pot and keep in a cool place such as a vegetable cellar until the roots show through the soil when tipped out of pot. After bringing into light they should be kept in as low a temperature as possible to get best results.

Giant Purity-Pure white. Giant bulbs. $75 \mathrm{c}$ per doz.

Purity-Pure white. Large bulbs. 50c per doz

Elder's Giant White-A sensational new kind. flowers are twice as large as any kind. flowers are twice as large

Largest bulbs $15 \mathrm{c}$ each,!\$1.25 per doz.

Gen. Pershing-Lavender-pink with yellow throat. Large bulbs 65 per doz.

Golden Daffodil-Beautiful, large, deep golden yellow flowers Largest bulbs $10 \mathrm{c}$ each, $\$ 1.00$ per dozen.

Golden Treasure-Very large canary yellow flowers. Largest bulbs 10c each, $\$ 1.00$ per dozen.

Mrs. Robert Craig - Large lavender blue flowers. Large bulbs $75 \mathrm{c}$ per doz.

Susanne Miller-Beautiful clear lavender blue flowers. Large bulbs $\$ 1.00$ per doz.

Rainbow Freesias-Yellow, blue, pink and lavender shades mixed. $65 \mathrm{c}$ per doz.

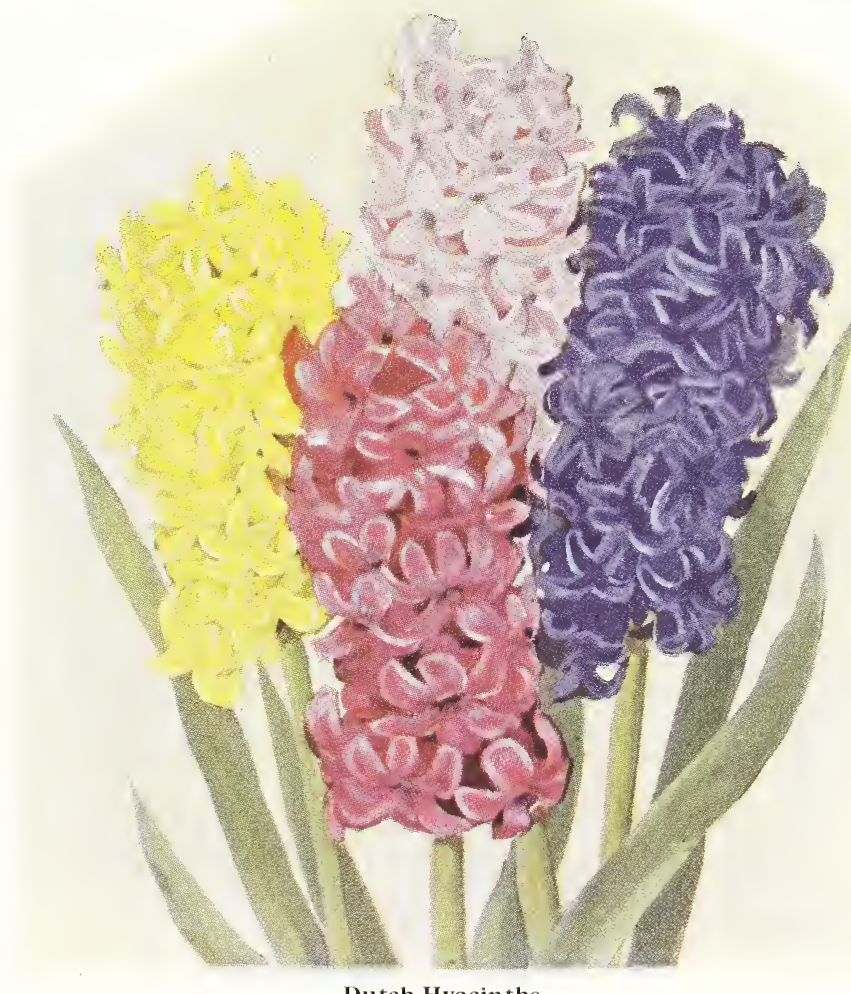

Dutch Hyacinths 


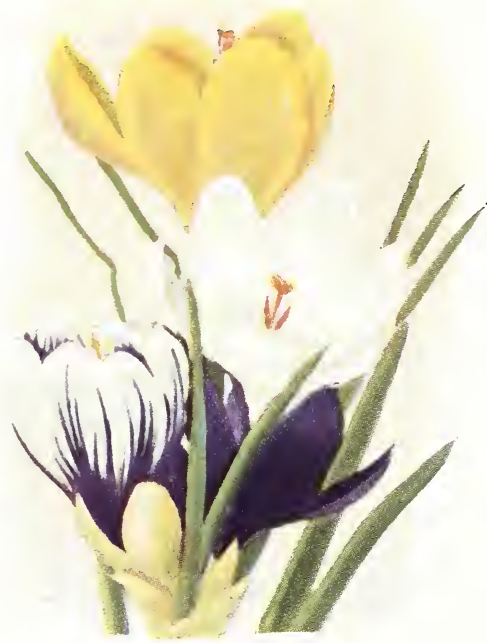

Crocus

\section{Crocus}

THESE bright, cheerful flowers are earliest of all to bloom. They are often in 1 bloom before the snow is gone. A few dotted about in clusters in the lawn is a mosiew from indoors. The colors come in bright golden yellows, deep lo light blue, striped and pure white. Plant them anywhere. Do not plant too , two inches, not to exceed four inches is best. They may also be grown in pots indoors. Treat same as Tulips or Hyacinths.

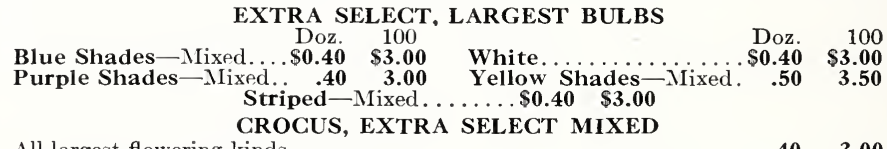
All largest flowering kinds.

Add 5 c per dozen if to be sent by parcel post.

\section{COLCHICUM-AUTUMN FLOWERING CROCUS}

The flowers of these curious plants do not appear until their foliage has died down. The bulbs should be planted in the rockery or in places where their growth during the early summer months will not be disturbed. The growth stops during July or early August and the fine large flowers come early in September and continue with a succession long after other flowers have been cut down by frost and severe weather. We offer very large bulbs of the two choicest kinds.

Au tumnale - Large, deep lavender flowers, giant bulbs. Per doz. \$0.40 per $100 \$ 4.00$ These curious bulbs will bloom profusely anywhere without soil or moisture. If laid on a window sill or table where light reaches them, they will burst into bloom in a few days.

Note-On account of their short fall blooming season, we do not expect to be able to supply blooming bulbs after October 1st.

Zonatus-Rose lilac, with yellow center. Ea. 10c, Doz. $\$ 1.00$, Per $100 \$ 7.00$

\section{MISCELLANEOUS BULBS}

Doz, $\quad 100$

Chionodoxas-Charming bright blue flowers blooming as soon as snow is off the ground.... \$0.40 $\$ \mathbf{\$ 3 . 0 0}$ Eranthis (Winter Aconite)-Brilliant yellow flow-

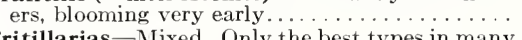

Fritillarias - Mixed. Only the best types in many $\mathbf{2 . 5 0}$

Ixias-A fine mixture of these bright, longstemmed flowers. Only suited to indoor culture
Muscari-Heavenly blue (Grape Hyacinth). Very early blooming, bright sky blue flowers...

\section{LILIES:}

Lilies that are desired for house culture should be potted firmly in good rich soil, with plenty of free drainage, and placed in a when tipped out of pot. They may then be placed in the light, not too warm at first, when they will start and continue to grow and bloom.

Lilium Harrisi-The Bermuda Easter Lily Each Doz. Early flowering. Very large bulbs. $\quad \$ 0.35 \quad \$ 3.50$ Lilium Giganteum-The Japanese Easter Lily.

The most popular Lily at Easter. Large bulbs.. $\quad .40 \quad \mathbf{4 . 0 0}$

Lilium Candidum - The Madonna Lily. This beautiful pure white lily is a great garden favorite. The bulbs should be planted as early in fall as possible in order to start grow th before cold weather. These bulbs arrive about September 1 st and for best results should be planted as early as possible.

Large bulbs...

Each \$0.35 Doz. $\$ 3.50$ Giant bulbs.

Each .50 Doz. 5.00

NOTE-Add $3 c$ each or $25 c$ per dozen if to be sent by parcel post.

\section{CALLA LILIES}

Aethiopica - The largest flowering white variety Each Doz. Extra large roots, dormant.

Little Gem-A smaller variety, but blooms very

Elliottiana (The Golden Yellow Calla) - Strong

dormant roots.................... $\mathbf{. 5 0} \mathbf{5 . 0 0}$

\section{CHINESE SACRED LILIES}

The bulbs we offer are American grown. These have proven to be just as good, if not superior, than those formerly imported from China.

These bulbs may be planted in soil, but are preferably grown in bowls of water, with pebbles to firm and hold them upright. Each bulb sends up from four to eight stems, producing great clusters of large waxy blossoms. with orange centers.

Largest size bulbs................ Each \$0.20 Doz. \$2.00 NOTE-Add $3 c$ each or $20 \mathrm{c}$ per dozen if to be sent by parcel post.
Oxalis Buttercup-Tine, large, yellow flow

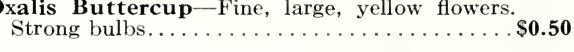

Oxalis, Duchess-Pink flowers. Strong bulbs... $\quad \mathbf{. 4 0}$

Scilla Nutans (English Blue Bell)-Strong bulbs $\mathbf{. 4 0} \quad \mathbf{\$ 3 . 5 0}$ Scilla Sibirica-Bright blue, star shaped flowers produced very freely.

Snowdrops-These popular little white flowers come peeping out of the ground just as soon as the snow is gone. Largest bulbs...................

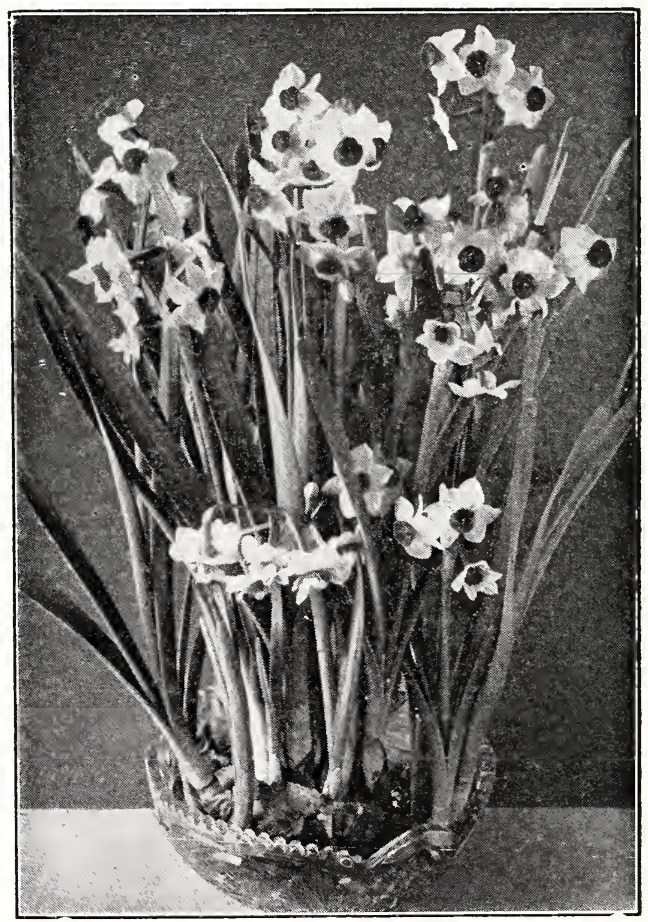

Chinese Sacred Lily 


\section{Exquisite Peonies}

THE Peony has the largest and most gorgeous 1 flowers of all perennials. Peonies grow easily, bloom profusely and are the pride of every garden.

PLANTING - The roots should be set with the "eyes" 2 to 3 inches below the surface and the soil tightly packed about them. Allow a spacing of about 3 feet between the plants. A ight covering of straw, after the ground has frozen, is desirable. 3 to 5 eyes. "Clumps" or older stock can be supplied at double the price of "roots."

\section{WHITE PEONIES}

Avalanche-A large globular cone-shaped flower of Each white. Very fragrant. Midseason.

Couronne d'Or-Snow-white with circle of golden stamens, Large blooms. Late. Excellent cut-flower.

Festiva Maxima-Early and very large. Center flaked crimson. Splendid in every way. Very popular.

Mme. Jules Dessert-Creamy white lighted with buff and salmon shades. Golden stamens add further beauty. 2.00

Mons. Dupont-A large-flowering, tall-growing white with erimson blotch on center petals...............

Primevere-Best yellow-tinted Peony. Creamy petals inclose a center of sulphur-yellow.

\section{PINK PEONIES}

Claire Dubois - A uniform shade of clear violet rose, tipped silvery white. Large flower. Late........... 1.00

Edulis Superba-A large rose type flower of deep pink. Blooms early.

Lady Alexandra Duff-Soft delicate pink. Sweetly fragrant. Large flower with broad petals.

Livingstone-Large full flowers of soft rose-pink with silvery tipped petals. Blooms late............ 1.00

Martha Bulloch-Shell-pink shading to deep rose-pink in center. Enormous flowers. Fragrant. Mid-season.... 5.00

Mons. Jules Elie-Lilac-rose with silver sheen. Very large; fragrant. Looks like a giant pink Chrysanthemum.

Reine Hortense-Delicate pink with center flecked crimson. Perfect flowers on tall, stiff stems. Mid-

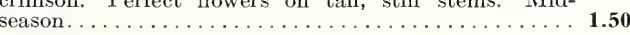

Sarah Bernhardt-Bright apple blossom pink with petals silver-tipped. Agreeable fragrance. Very popular. 1.25

Solange - Creamy-white with deep orange-salmon tints. Large, full, compact unusual and exquisite flower.... 3.00

Souv. De Louis Bigot-An extra fine and large flower of rich salmon-pink. A striking color ............ 3.00

Therese-Unexcelled light pink. Large, exquisitely lovely flowers of true rose type. Delightful fragrance.. 2.75

Walter Faxon-A brilliant salmon-pink. Mid-season. A vivid and outstanding color.

\section{CHOICE PEONY COLLECTION}

All large-flowering, double Peonies. 6 good varieties-all different. 2 reds, 2 whites, 2 pinks.

(Value \$4.50) SPECIAL PRICE...

(Postpaid)

\section{RED PEONIES}

Charles McKellip - A deep, bright red of semi-rose form Midseason. Broad silky petals.

Felix Crousse-Bright rose-red. Large globular flower Fragrant. A profuse bloomer.

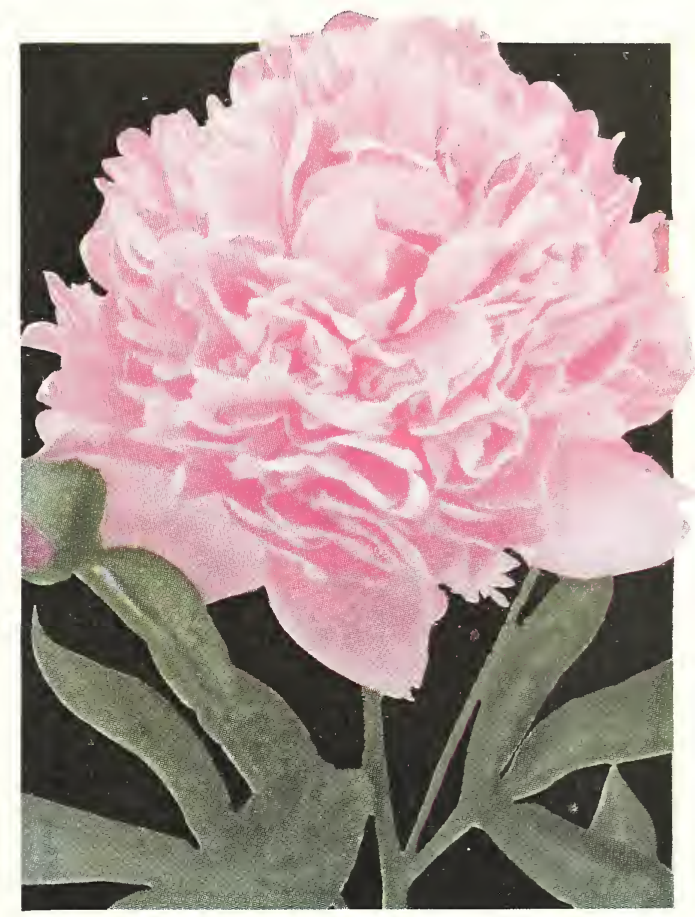

Sarah Bernhardt Peony

Grover Cleveland-Dark crimson. Large flowers of rose type. Vigorous grower. Late.

Karl Rosefield-Rich, glowing crimson. Immense, solid flower. Superb variety with abundance of blooms.... .75

Longfellow-Crimson with cherry tones. One of the best bright reds. Color never fades.

Mary Brand-Decp red. Mid-season. Large flowers in profusion. A Minnesota origination.

Mons Martin Cahuzac-Darkest maroon-red peony. A large, full and unuel flower.

Officinalis Rubra-The earliest red. An old favorite. Always blooms.

Tenuifolia F1. P1.--Very early double crimson flowers. With finely-cut, fern-like foliage. Most unusual plant. . 2.50

\section{JAP and SINGLE PEONIES}

Popular taste is rapidly awakening to the beauty and eharm of these striking flowers. Within the outer row of large guard petals there are smaller petals or brilliant yellow stamens. The flowers are splendid for garden display or for cutting.

Albiflora (The Bride)-Large flower with silky white petals and long yellow stamens. Fragrant........\$1.00

Exquisite (Jap) - A beautiful white from Japan with

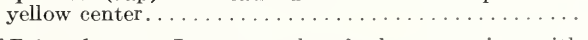

L' Etincelante - Large petals of clear carmine with
silvery margins. Decidedly cup-shaped.............

Marie Jacquin-Delicate flesh-white, commonly called "the water lily"......................... 1.00

Mikado (Jap)-Dark crimson. Like a giant red poppy. Gold center. Blooms freely ..................

Pride of Langport $\rightarrow$ Soft peach-pink with golden stamens. Exquisite. The early single flowering red with cut-leaf

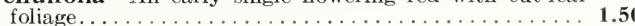




\title{
Perennial Flowers
}

\author{
HARDY PLANTS TO PLANT THIS FALL
}

$\mathrm{SUCH}$ varieties as are listed here $D$ are selections of the hardier sorts and can be advantageously planted in the FALL-preferably early FALL.

IMPORTANT PLANTING NOTEAfter the ground has frozen a covering of straw or hay, several inches deep, should be spread over the new plantings as a winter protection.

For more complete lists of the hardy plants see our large catalog "Home Landscapes". A copy will be mailed on request

\section{PRICES OF PERENNIALS}

Unless otherwise noted plants are $\mathbf{3 5}$ cents each, 3 for $\$ 1.00$. Older 2year plants are 50 cents each.

\section{QUANTITY RATE}

5 or more of a single variety will be supplied at 5 cents less per plant, that is, plants at 35 cents each are

$$
5 \text { for } \$ 1.50 \text {. }
$$

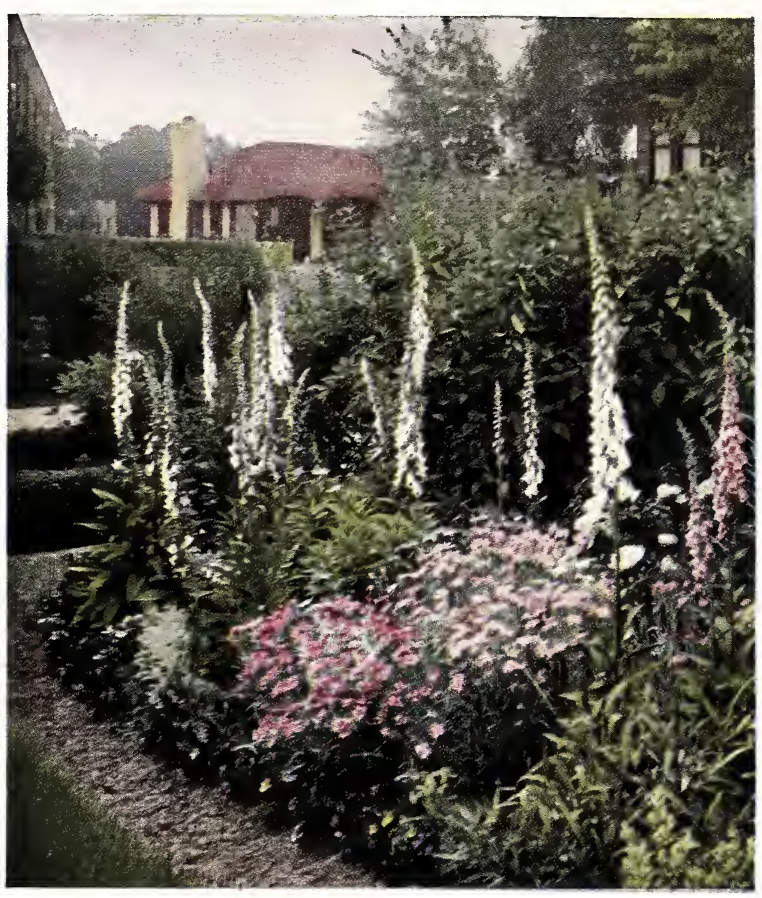

Plant a border of cheerful perennial flowers.

ARABIS, Rock Cress--Early, white border plant. A dependable rock garden plant.

ASTER, Hardy New England Aster-Both pink and purple varieties. Very showy fall flower that blooms right up to heavy frosts.

ASTILBE Spiraea-Flowers of pink or white in airy plumes. 50c, 2-year 75c.

BABY'S BREATH (Gypsophila)-The plants are covered with a cloud of dainty white flowers in July and August.

DOUBLE BABY'S BREATH (Bristol Fairy)-A choice new variety. The flowers are tiny, fully-double white rosettes. Strong plants of the grafted variety. \$1.00 each.

BLEEDING HEART-Pink flowers in drooping elusters in eariy spring. 60c, 2-year $\$ 1.00$.

PLUMY BLEEDING HEART-Dwarf variety with fern-like leaves. 40c, 2-year 60c.

BoCCONIA, Plume Poppy-A tall-growing background perennial with plumes of creamy-white flowers.

BOLTONIA-The tall-growing Fall Daisy.

CAMPANULA CARPATICA, Harebell-Delicate bellshaped flowers of blue or white.

CENTAUREA-The blue perennial corn flower.

COLUMBINE-See Aquilegia.

COREOPSIS-Golden yellow daisy on long stems. A fine cut flower. Price 30c.

DAISY Hartje and Elder (New) - A pure white Decoration Day Daisy. Large flowers and strong stems. Very popular for cutting. Price 30c.

DELPHINIUM (Larkspur)

-Chinese-White or blue flowers. Finely cut foliage. Very dainty and valued for cutting.

-Belladonna-Turquoise-blue larkspur. Tall.

-Bellamosa-Dark blue flowers. Tall.

- Hybrids-Large heads of showy flowers in varied shades of blue. Very desirable. 


\section{Perennial Flowers-Continued}

DIANTHUS, Clove Pink-A dwarf-growing hardy pink. Good rockery plant.

FERNS-The hardy, native kinds. 40c, 2-year 60c.

FILIPENDULA, Crimson Meadow Sweet-Open clusters of pink flowers in mid-summer.

FUNKIA, Blue Plantain Lily - A splendid dwarf border or edging plant. Stands shade. Has drooping lily-flowers of

FUNKIA, Variegated-Tufts of broad, waxy-green leaves striped with white. $40 \mathrm{c}, 2$-year plants $60 \mathrm{c}$.

GAILLARDIA - A red and yellow daisy-like flower. Price 30c. HEMEROCALLIS, Flava-The Lemon Day Lily.

HEMEROCALLIS, Fulva - The Orange Day Lily.

HEUCHERA, Coral Bells-Dainty coral-pink and red bellshaped flowers. Excellent for cutting. 40c, 2-year 60c.

IRIS-See special list page 21.

LILY OF THE VALLEY-25c, 2-year 40c.

LY'THRUM, Rose Loosestrife-A tall perennial with spikes of rose-colored flowers.

MERTENSIA, Blue Bells. Bright blue flowers that come in early spring with the tulips. Price 35c each, 3 for $\$ \mathbf{1 . 0 0}$.

MONARDA, Oswego Tea-A bushy plant with fragrant leaves and red flowers in July.

PEONIES-See special lists page 17.

PERSIAN DAISY - White, pink and red daisies in May and June. 30c, 2-year 50c

PHLOX - See special lists page 20

PLATYCODON, Balloon Flower-Star shaped flowers in blue or white.

POPPY, Oriental-The large scarlet poppies 35c

New Named Varieties 50c each-as follows:

-Beauty of Livermore-Crimson with dark shadings.

-Mrs. J. Harkness-Bright Salmon pink.

-Mrs. Perry-Orange Apricot.

-Olympia-Brilliant flame scarlet overlaid with golden salmon.

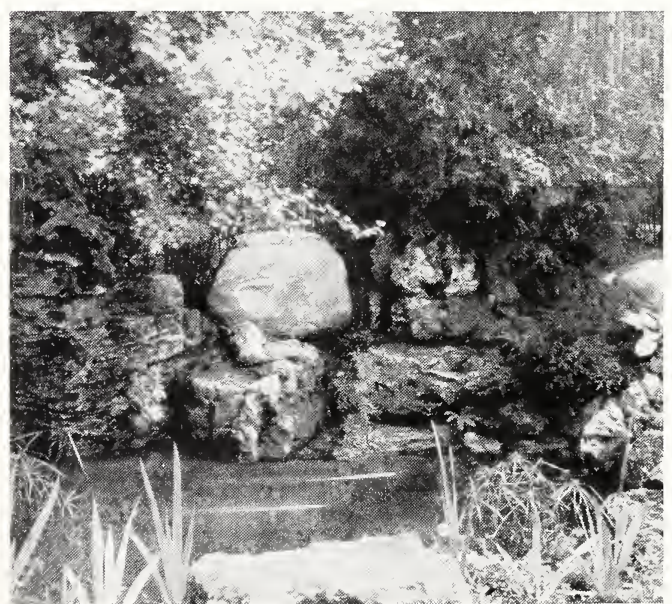

A Rockery Will Add New Interest to Your Yard

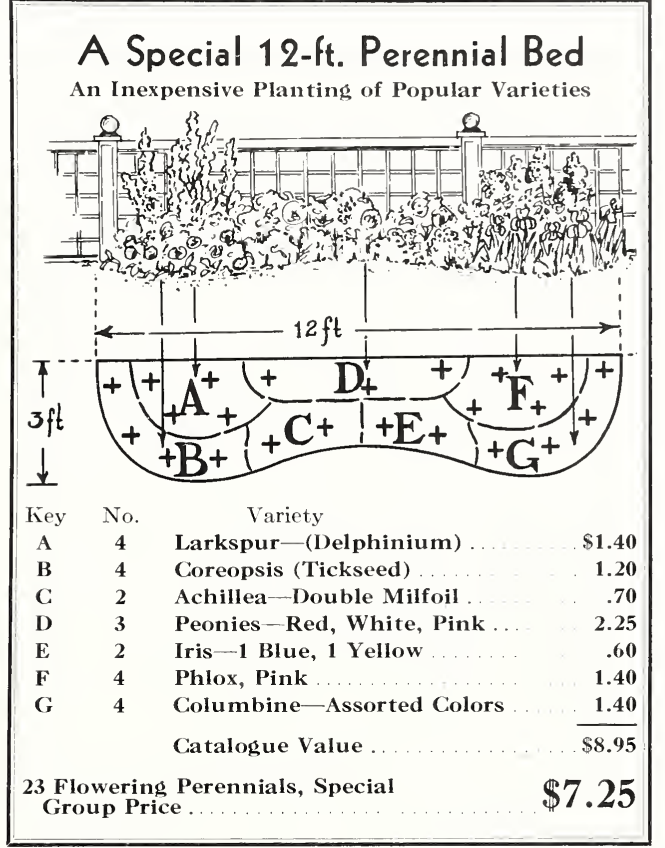

PYRETHRUM, Fall Daisy-The tall Ox-eye daisy that blooms in September.

SEDUM, Acre-Dwarf perennial with golden flowers. Good rockery plant.

SEDUM, Spectabile-Rose colored flowers in August and September. Heavy fleshy leaves.

SHASTA DAISY - Good cut flower. White Daisy

STATICE, Sea Lavender-A mist of small light blue flowers. Often dried for winter bouquets.

TROLLIUS, Yellow Globe Flower-A large double buttercup like flower in early spring. Unusual. 40c, 2-year 60c.

TROLLIUS, Orange Variety - A globe flower of a bright orange color. 40c, 2-year 60c.

VALERIANA, Garden Heliotrope-Sweetly fragrant graypink flowers.

VERONICA, Speedwell-A medium height plant with blue flowers in spikes. Good for cutting.

VIOLA, Jersey Jem-Blue flowers like small pansies all summer long. 30c.

\section{BUILD A ROCK GARDEN}

Enjoy A New Gardening Adventure

A Rock Garden is simple to make and easy to care for. A Rockery will fit naturally into a slope or terrace and can be made appropriate even on level areas by providing a background of Evergreens, trees or shrubs.

\section{Rockery Suggestions Free}

Send for our pamphlet on Rock Garden construction with lists of hardy alpine plants.

\section{SPECIAL \\ ROCKERY COLLECTION}

15 choice Perennials - 3 each of 5 of the best varieties. All labeled. Our selection. Value $\$ 5.25$.

Special Price (postpaid) $\$ 3.90$ 


\section{Bright Phlox}

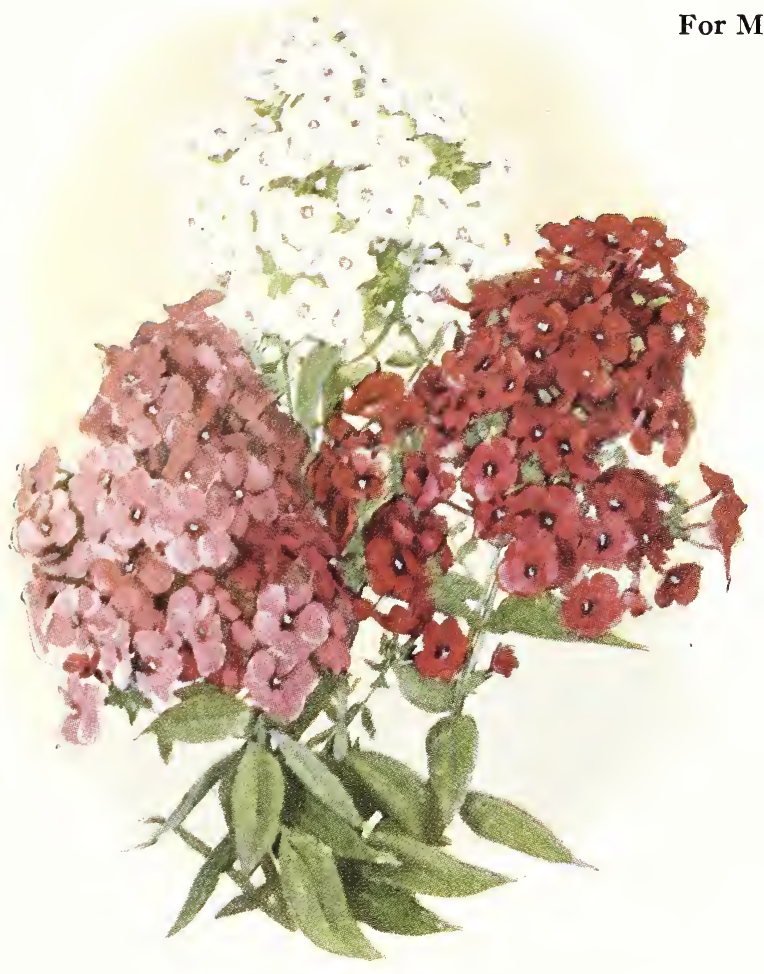

DHLOXES are very hardy floriferous perennials that give bold, brilliant color effects from July to frost.

Where to Plant-They are exceedingly attractive when planted in masses of a single kind in a bed or border. Their midsummer bloom makes them a most valuable addition to beds where such spring-blooming plants as Iris, Peonies, Poppies, Etc., are located.

Planting-Space the plants 15 to 18 inches apart and set the roots about 2 inches below the ground surface, making sure that the new eyes are well covered. Af ter freezing weather cover these new plantings with a light mulch of straw or hay.

\section{PRICES}

(Unless otherwise noted) Plants 35 cents each, 3 for $\$ 1.00$.

\section{QUANTITY RATE}

5 or more of a single variety will be supplied at 5 cents less per plant, that is, plants priced at 35 cents each are $\$ 1.50$ for 5 .

\section{RED PHLOX}

B. Comte-Bright purplish-crimson with satiny sheen. Medium height. One of last to flower.

Coquelicot-A bright orange-scarlet of outstanding color. $35 \mathrm{c}, 2$-year 50c.

Dr. Konigshofer-Brilliant orange-scarlet, with dark bloodred eye. Medium height, midseason. 35c, 2-year 50c.

Fireglow-An outstanding brilliant flower of orange-scarlet. Blooms freely. 40c, 2-year 60c.

Gen. Van Heutz-Brilliant salmon-red, with light center changing later to deep red eye. 35c, 2-year 50c.

Mme. Bezanson-Rich crimson, medium height. 35c, 2-year $50 \mathrm{c}$.

R. P. Struthers-Rosy carmine with claret-red eye. Very bright; tall. 35c, 2-year 50c.

\section{WHITE PHLOX}

Frau Anton Buchner-Undoubtedly the finest white Phlox which has as yet been raised. Large flowers of perfect form. $35 c, 2$-year 50c

F. G. Von Lassburg-Purest white: individual flowers very large. Tall, mid-season. 35c, 2-year 50c.

Miss Lingard-The most popular white. Immense heads of white flowers in late June and again in September. 35c, 2-year 50c.

Mrs. Jenkins-Immense trusses of pure white flowers. Early $35 c, 2$-year 50c.

Mia Ruys - The finest of the dwarf white Phlox. Snow-white flowers of large size. Height 8 to 9 inches. 35c, 2-year 50c.

\section{LAVENDER AND PURPLE PHLOX}

Eugene Danzanviller-Soft lavender shading lighter to center. 35c, 2-year 50c.

Champs Elysees-Large trusses of dark crimson-purple, medium height. 35c, 2-year 50c.

Mrs. Chas. Dorr $-A$ beautiful shade of lavender. Very large conical heads. 35c, 2-year 50c.

\section{PINK PHLOX}

Elizabeth Campbell-Very large heads, with flowers of quite a new color-light salmon changing to pink in the center. 50c, 2-year 75c.

Mme. Paul Dutrie-Opens a soft lilac-rose which gets lighter as it ages. 35c, 2-year 50c.

Pantheon-Deep Salmon-rose; light center. Very large flower. Tall. 35c, 2-year 50c.

Rheinlander -A most beautiful salmon-pink with deeper center. Immense size. 35c, 2-year 50c.

Rijnstroom-A lovely rose pink, much like Paul Neyron rose. Very large flower heads. 35c, 2-year 50c.

Thor-A rich salmon pink with crimson eye. 35c, 2-year 50c. W. C. Egan - Soft shade of lilac with dark pink eye. General effect is a soft rose color. 35c, 2-year 50c.

\section{A NEW EARLY PINK}

Miss Verboom-Blooms in June with the Miss Lingard White Phlox and bears long heads of rose-pink with bright glossy-green foliage that is free from rust $\mathbf{- 5 0}$ cents.

\section{WHITE WITH PINK EYE}

Bridesmaid-Tall, with flowers of pure white, with large crimson-carmine eye. 35c, 2 -year 50c.

\section{DWARF PHLOX FOR BORDERS}

Phlox Subulata-An early spring-flowering type which during the flowering season is a mass of bloom. An excellent plant for the rockery and border, and invaluable for carpeting the ground or covering graves.

Pink or White-25c, 2-year 40c.

Divarica ta-Large, fragrant, lavender flowers on stems 9 inches high in April and May. An excellent hardy Phlox. Price $35 \mathrm{c}, 3$ for $\$ 1.00$.

\section{SPECIAL HOME YARD PHLOX COLLECTION}

10 field-grown roots, 2 each of 5 standard varieties, selected for variation in colors. Value $\$ 3.50$.

Special Combination Price

(10 plants) ...............\$2.85

Parcel Post Prepaid 


\section{Colorful Iris}

RIS is brilliant in the garden and splen1 did for cut flowers.

How to Plant-Place the roots just deep enough to be covered with soil. A mulch of hay or straw spread over the new plantings, after the ground has frozen, is a good winter protection.

\section{QUANTITY RATE}

5 or more of a single variety will be supplied at 5 cents less per plant, viz.: plants priced at 35 cents each are $\$ 1.50$ for 5 .

NOTE. In the description "S" or "Standards" refers to the three upright petals. The letter " $F$ ", or "Falls" refers to the three drooping or lower petals.

Ann Page (Lavender) - Lovely pale lavender blue. Large quite fragrant flowers on stout stems.

Each

Ambassadeur (Smoky Bronze) - S., redviolet: $F$, velvety purple maroon. Outstanding variety, rich in color and beauty. .

Asia (Lavender and Gold) - Unusually large flower with silvery lavender standards and violet falls .

Aurea-(Yellow)-Excellent garden variety of yellow color

Caprice (Red Tones)-S., reddish purple; F., deeper claret. Grape fragrance

Dream (Pink) - Lovely rose pink with orange beard. A tall-growing, graceful variety...

Fairy - (Blue White) - Soft white with blue glow in depth of flowers. A favorite white.

Gold Imperial (New) (Yellow) - Particularly clear colored yellow with brilliant orange

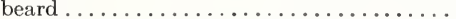

is King (Yellow and Red)—S., buff yellow F., Maroon with gold border.............

Juniata (Mauve Violet)-Tall, clear blue violet $\mathbf{. 3 0}$

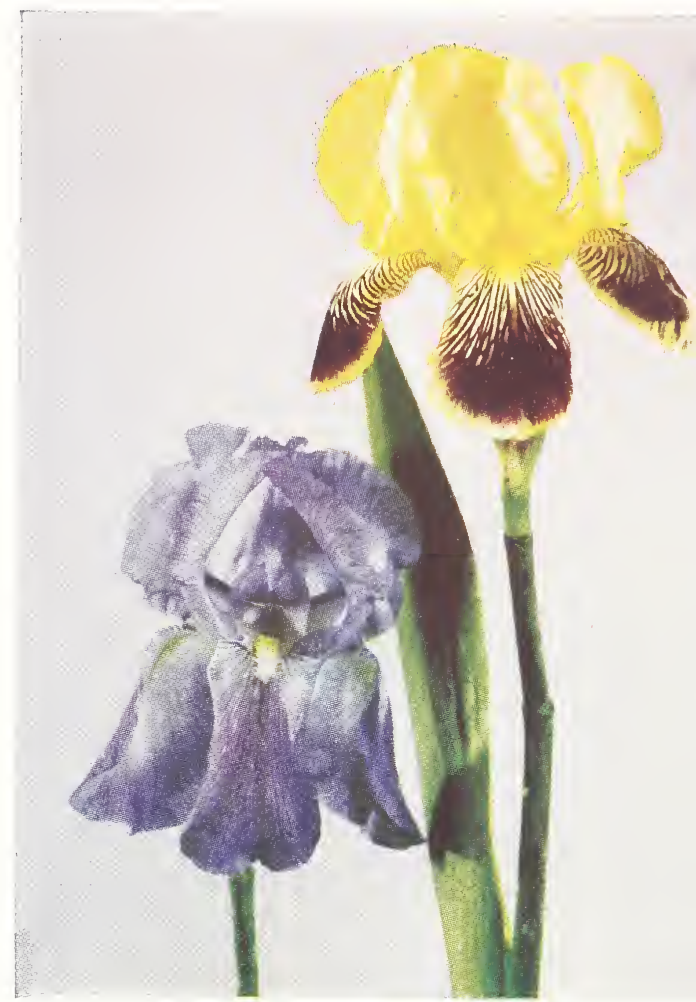
standing Iris with large flowers. S., soft violet: F royal purple.

ord of June-An immense flower of clear lavender blue.

Very popular. An immense flower of clear lavender blue.

Loreley (Yellow and Violet) - S., light yellow; F., purple

bordered yellow....... light lavender with bronze at

Majestic (Purple) - S., light lavender with bronze at $\begin{array}{rr}\text { base; } F ., \text { velvety raisin purple. An enormous flower. . } & \mathbf{1 . 0 0} \\ \text { Medrano-Reddish maroon in effect................ }\end{array}$

Monsignor (Deep Blue Effect)-S., bluish violet, $\vec{F}$., purple with white veinings.

Morning Splendor (Red Purple) -S., petunia violet $\mathrm{F}$, raisin purple. Yellow beard. Judged to be the finest American Iris, Luxuriant in growth.

Mother of Pearl-A light, soft lavender with pearly

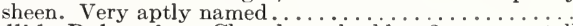

Pallida Dalmatica-Clear lavender-blue flowers on tall strong stems.

Parc de Neuilly (Violet Effect) - - S., arched and ruffled; F., drooping. A reliable purple ..... light blue; $F$. . rich
Perfection (Blue Purple Effect) dark velvety violet.

Prairie Gold (New) - A deep rich yellow. Large flowers and sturdy growth. The finest dark yellow...

Princess Beatrice (Silvery Lavender) $-\mathrm{S}$., cupped light

lavender: $\mathrm{F}$. flaring. Bright, clear color.

Prospero-S., deep lavender; F., rich violet-purple. Large flowers.

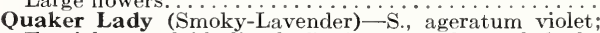
F., violet overlaid olive buff. An unusual pastel shade

0.25

\section{RED and PINK IRIS}

These will add new color to your older Iris plantings. 6 sturdy roots of 6 different pink and red tinted Iris.

Special Collection Price.

(Postage Prepaid)
$\$ 1.60$
IRIS Parc de Neuilly and IRIS King (right)

Rhein Nixie (Purple and White)-S., white; F. pansy violet edged white................................... purple falls. Large flower. Rapid grower Seminole (Wine Red Effect) - S., frilled petals of reddish tone; F., a deeper raisin purple. Brilliant in color the deeper raisin purple. Brillian

Souvenir de Mme. Gaudichau (Rich Purple) - A large Souvenir de Mme. Gaudichau (Rich Purple) and richly-colored dark, velvety purple flower . . . . . . .50 Taj Mahal -A white Iris of pure color and tall growth.. $\quad .75$ Tenebrae (Rich Purple Effect) - S., violet purple tinged

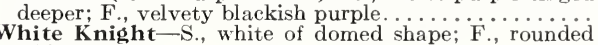
white petals.

\section{DWARF IRIS (Pumila)}

Well Suited to Rock Gardens

These early-flowering, dwarf Iris are particularly suited for rock gardens and for edging beds and borders.

Yellow, Blue or Purple.

\section{SIBERIAN IRIS}

Very attractive for garden display and particularly for cutting. Flowers on graceful stems; foliage narrow and grass-like.

Siberian Blue-A good violet blue.

Snow Queen —A delicate ivory white $\ldots \ldots \ldots \ldots \ldots \ldots .25$

\section{HOME YARD IRIS COLLECTION}

A special collection that will make a colorful Iris planting. 12 Choice Roots -2 each of 6 different kinds. Value $\$ 3.00$.

\section{Special Group Price}

(Postage Prepaid)
Each 0.25 


\section{Flowering Shrubs}

THERE is a real advantage to planting the 1 hardier shrubs in the Fall so that they can listed selected carefully from our large general stock are recommended for Fall planting.

More complete descriptions will be found in our large catalogue, "Home Landscapes." Sent on request.

\section{DWARF SIZE SHRUBS}

FOR BORDERS AND FOREGROUND PLANTINGS

Each

BARBERRY, Japanese - The most useful

dwarf shrub. Has red berries and brilliant fall foliage color.

12 to $18 \mathrm{in}$. 18 to 24 in.

BARBERRY, Red Leaved - A new shrub with rich red colored leaves that holds the color all summer.

15 to 18 in

CURRANT, Dwarf Mountain - A dwarf shrub of dense growth. Thrives anywhere in sun or shade. Can be trimmed and sheared.

12 to 18 in.

12 to $18 \mathrm{in}$

SPIRAEA, Anthony Waterer-A dwarf shrub with crimson flowers. Very useful in house foundation plantings and in the foreground of larger shrubs,

12 to 18 in.

18 to 24 in.

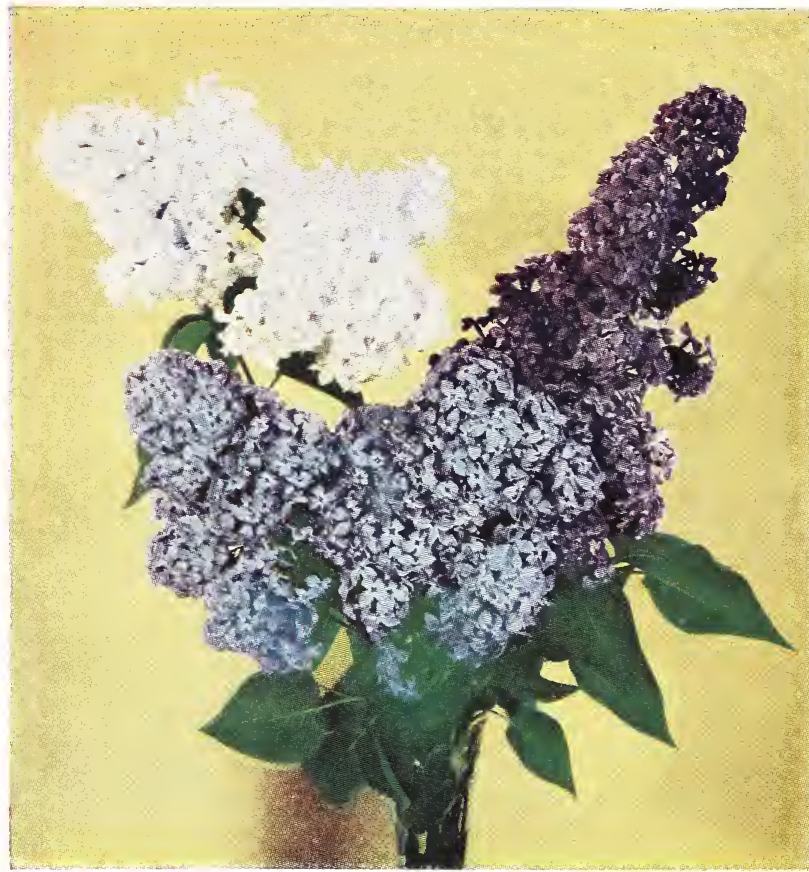

SPIRAEA, Callosa Rosea-A splendid dwarf shrub. Pink flowers in flat-topped clusters. Long blooming season. Quite hardy

18 to 24 in

$\$ 0.50$

24 to 30 in

SPIRAEA JAPONICA-A dwarf shrub bearing white flowers in abundance. Long blooming season. 18 to 24 in..
$\$ 0.35$

1.25 .40 .40

The new French Lilacs offer a choice of colors. (See Page 23)

SYRINGA, Golden Leaved-A desirable shrub with bright yellow leaves. Very well suited to brighten up the color of shrub plantings. 18 to $24 \mathrm{in} . \ldots \ldots \ldots \ldots \ldots . \$ 1.25$

\section{MEDIUM HEIGHT SHRUBS}

\section{FOR HOUSE FOUNDATION PLANTINGS AND WHERE SHRUBS UP TO 4 FEET HIGH ARE WANTED}

CORALBERRY - Red fruits in fall. Medium height shrub. Grows well in partial shade. 2 to $3 \mathrm{ft}$.

COTONEASTER - A very ornamental shrub with handsome dark green foliage.

18 to 24 in.

2 to $3 \mathrm{ft}$.

3 to $4 \mathrm{ft}$.

CURRANT, Flowering-Fragrant yellow flowers in Spring. Grows well in the shade. An old favorite. 2 to $3 \mathrm{ft}$.....

3 to $4 \mathrm{ft}$

ELDER, Cut Leaved-An unusual shrub with cut and fern-like leaves. There are creamy-white flowers in June. 2 to $3 \mathrm{ft}$. Each. \$0.50 3 to $4 \mathrm{ft}$. Each

ELDER, Golden Leaf-One of the best of the yellowleaved shrubs. 3 to $4 \mathrm{ft}$...

HYDRANGEA, P. G.-Large white, conical flowers that change to pink in Fall.

18 to 24 in. Each.....\$0.60 2 to $3 \mathrm{ft}$. Each.....

IIYDRANGEA, Snowhill-Large snowball-like, white flowers in mid-summer. Will grow well in partial shade. 18 to 24 in. Each..... \$0.60 2 to $3 \mathrm{ft}$. Each...... .75

RUGOSA ROSE (Japanese)-Hardy bush rose with light pink flowers and handsome crinkled leaves. 2-year. .

SNOWBERRY, White-Has slender, graceful branches that bend to the ground under its load of showy, white berries in the fall.

2 to $3 \mathrm{ft}$. Each.

$\$ 0.50$
SPIRAEA ARGUTA-(Meadow Sweet)-The best early flowering Spiraea. 2 to $3 \mathrm{ft} . \ldots \ldots \ldots \ldots \ldots \ldots \ldots \ldots$

SPIRAEA, Billardi-Bears spikes of pink flowers in midsummer when there are few other shrubs in bloom. 2 to $3 \mathrm{ft}$

SPIRAEA, Sorbifolia (Plume Spiraea)-Handsome, rapidly-growing shrub with leaves like the Mountain Ash. Bears long plumes of white flowers.

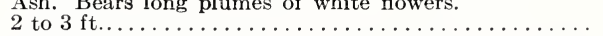

SPIRAEA Van Houttei (Bridal Wreath) - The most popular of all hardy shrubs. The flowers make a bank of white about Decoration Day.

2 to $3 \mathrm{ft}$.

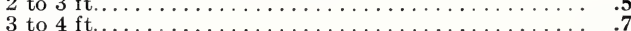

4 to $5 \mathrm{ft} \ldots \ldots \ldots \ldots \ldots \ldots \ldots \ldots \ldots \ldots$

SYRINGA, Lemoine's Variety-A useful, refined shrub of medium height. Good foliage and abundance of

fragrant, white flowers.

2 to $3 \mathrm{ft} . .$.

SYR INGA, New Double (Virginal Philadelphus)-A new and choice shrub with large fully-double and fragrant white flowers. See illustration page 23 2 to $3 \mathrm{ft}$. - strong plants.

\section{HELPFUL LANDSCAPE SERVICE}

Whether your needs are extensive or concern only a few shrubs for the door-yard, our experienced gardeners can help you with practical advice. Consult us. 
You Will Benefit

by ordering early. Orders are filled in rotation as received, and are marked for shipment at the best time for your use.

Order Early and be assured of a choice selection and a timely planting.

\section{Planting \\ Instructions}

are sent with our acknowled gement of your order.

\section{Parcel Post} Allow for postage if you want shipment by mail.

\section{ORDER SHEET AND ENVELOPE \\ THE PARK NURSERIES}

HOLM \& OLSON, ING.

Growers of Hardy Plants for Northern Garden:

20-24 W. 5th St. St. Paul, Minn.

Date Ordered

Ship to

Streot

City

County State

Ship By：Exp. $\square$ Freight $\square$ Name of R.R.

Charge to

(II Different)

Address

CATALOGUE PRICES ARE NET. F. O. E. SAINT PAUL

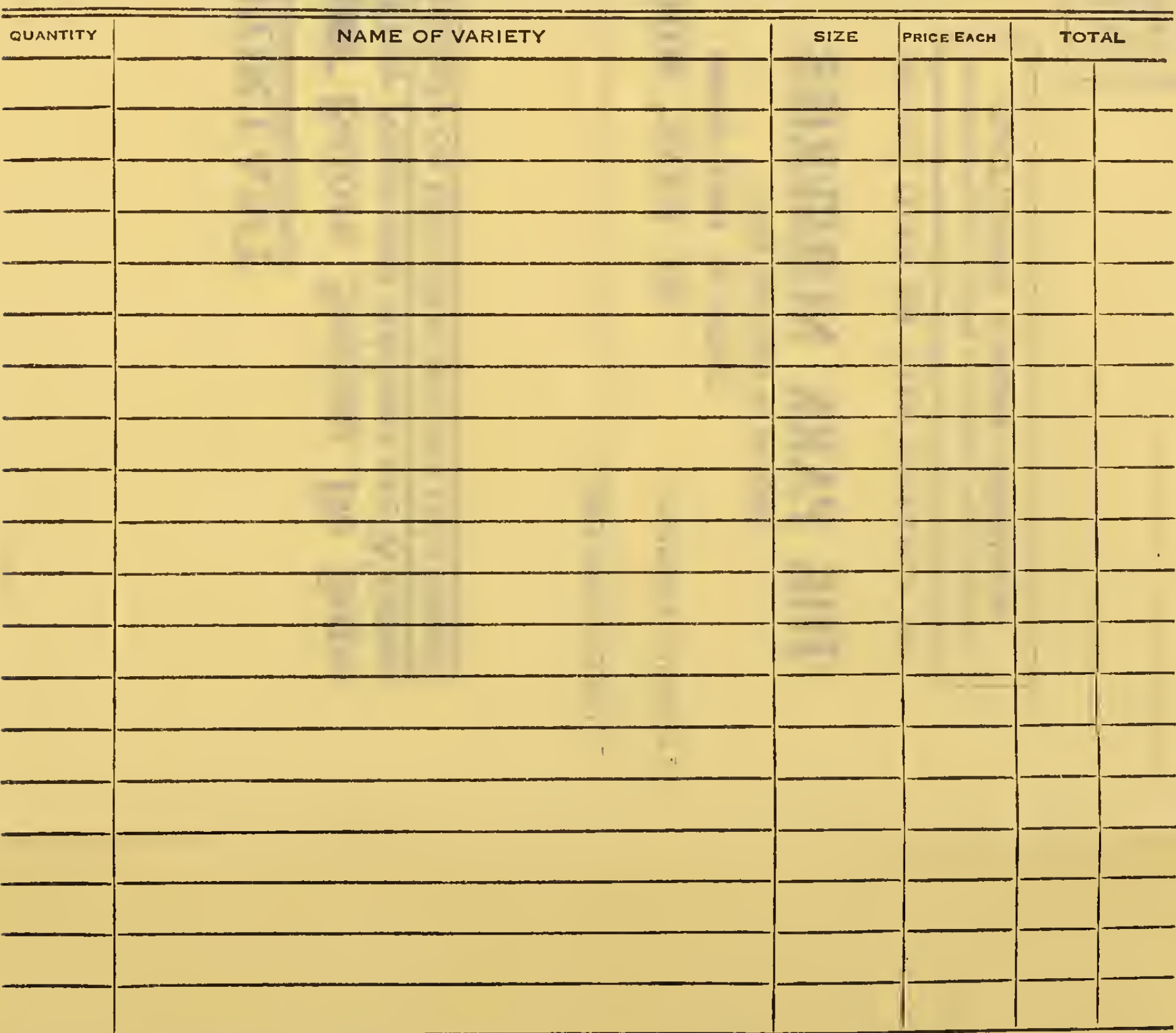

May we substitute an equally good variety if any of kinds ordered are exhausted? No...... Yes......

The foliowing parties may be interested in your catalog and landscape suggestions: 


\section{BUSINESS REPLY ENVELOPE}

NO POSTAGE STAMP NECESSARY IF MAILED IN THE UNITED STATES

3c-POSTAGE WILI BE PAID BY-3c

\section{THE PARK NURSERIES} (HOLM \& OLSON, Inc.)

20-24 W. Fifth Street

Landscape Architects ST. PAUL, MINN.

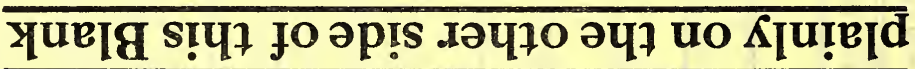

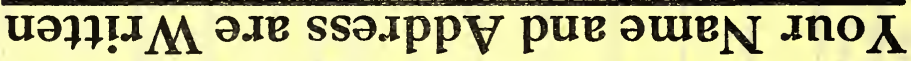

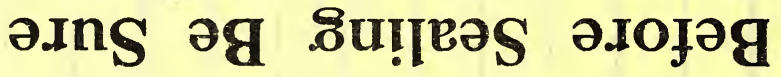




\section{Flowering Shrubs-Continued}

TALL GROWING SHRUBS

For Background Planting and Where a Substantial Shrub of Good Height is Needed.

DOGWOOD - A substantial shrub with both yellow and

red colored bark varieties.
2 to $3 \mathrm{ft}$. Each....\$0.50 3 to $4 \mathrm{ft}$. Each....\$0.7

EUONYMUS - The Strawberry Bush. Medium height

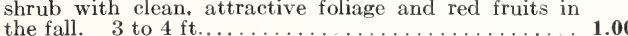

HONEYSUCKLE, Morrowi-A popular shrub of spreading growth. Bright red berries follow the creamy-white flowers. 2 to $3 \mathrm{ft}$. Each....\$0.50. 3 to $4 \mathrm{ft}$. Each.. .75

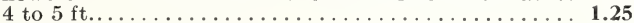

HONEYSUCKLE, Tartarian-A big graceful shrub with both pink and white flowering varieties. Red berries
follow the flowers. 2 to $3 \mathrm{ft}$. Each. \$0.50. 3 to $4 \mathrm{ft}$. Each. .75 LILAC-The old-fashioned white or purple lilac.

2 to $3 \mathrm{ft}$. Each....\$0.60 3 to $4 \mathrm{ft}$. Each.

.90

\section{NEW LILACS}

LILAC, Choice French Hybrids-New, improved Lilacs with heavier flowers than the old form. French lilacs are offered in white, purple, reddish-purple, bluelilac and pink-lilac.

2 to $3 \mathrm{ft}$. Each.............. $\mathbf{\$ 1 . 5 0}$

3 to $4 \mathrm{ft}$. Each.............. 1.75

LILAC, PERSIAN-Graceful growth; small leaves, and many very fragrant flowers in late spring.

2 to $3 \mathrm{ft}$. Each.... \$1.00 3 to $4 \mathrm{ft}$. Each...... 1.25

SIBERIAN PEA TREE (Caragana)-Hardy, bright yellow-flowering shrub. Always desirable where a tall shrub is wanted.

2 to $3 \mathrm{ft}$. Each.....\$0.50 3 to $4 \mathrm{ft}$. Each..... .7

SPIRAEA AUREA, Golden Leaved-A sturdy bush with bright yellow leaves. Pleasing for contrast. 2 to $3 \mathrm{ft}$. Each....\$0.50 3 to $4 \mathrm{ft}$. Each.

SPIRAEA OPULIFOLIA (Ninebark)-A large spreading bush with heavy foliage. Good background shrub. 2 to $3 \mathrm{ft}$. Each....\$ \$0.50 3 to $4 \mathrm{ft}$. Each.

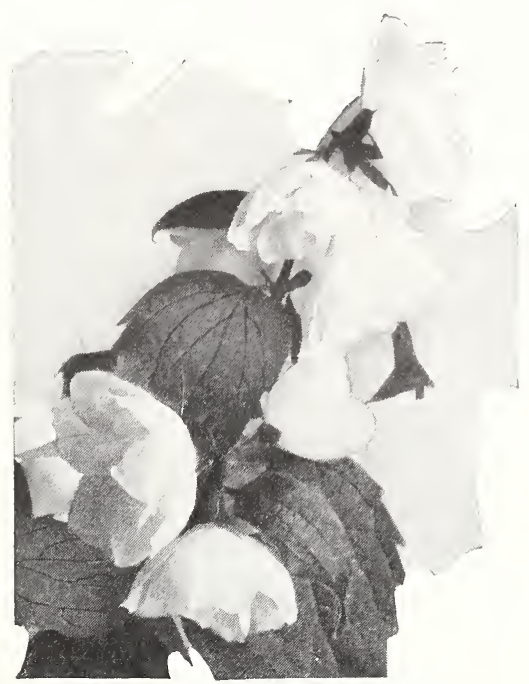

SYRINGA (Philadelphus) VIRGINAL

A New Double-Flowering Mock Orange

SYRINGA (Philadelphus)-Sweet Mock-Orange-Clusters of fragrant white flowers in June. Dependable, tall shrub.

2 to $3 \mathrm{ft}$. Each....\$0.50 3 to $4 \mathrm{ft}$. Each..... $\mathbf{. 7 5}$

VIBURNUM DENTATUM (Arrow Wood)-Very ordach mental foliage of glossy green. White flowers followed
ment by blue berries. 3 to $4 \mathrm{ft} \ldots \ldots \ldots \ldots \ldots \ldots \ldots \ldots \ldots \ldots \$ 1.00$

VIBURNUM (High Bush Cranberry)-Tall growing shrub with bright red berries. Bright autumn foliage coloration.

2 to $3 \mathrm{ft} .$. .

.80

1.00

\section{VINES-For Shade and Beauty}

Each

BETA GRAPE (Ornamental, hardy, grape)-2-year $\$ 0.50$ plants.
BITTERWEET (Glossy foliage, scarlet fruits) -2 -year

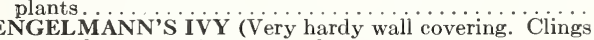

to brick or stucco) - 2-year plants.
HONEYSUCKLE, Scarlet Trumpet-2-year

MATRIMONY VINE (Lycium Chinense)-2-year

plants.
VIRGINIA CREEPER, Native Ivy-2-year

plants.
Each

50.60

.60

.50

NOTE-Strong, 3-year vines can be supplied in all varieties at $20 \mathrm{c}$ extra per plant.

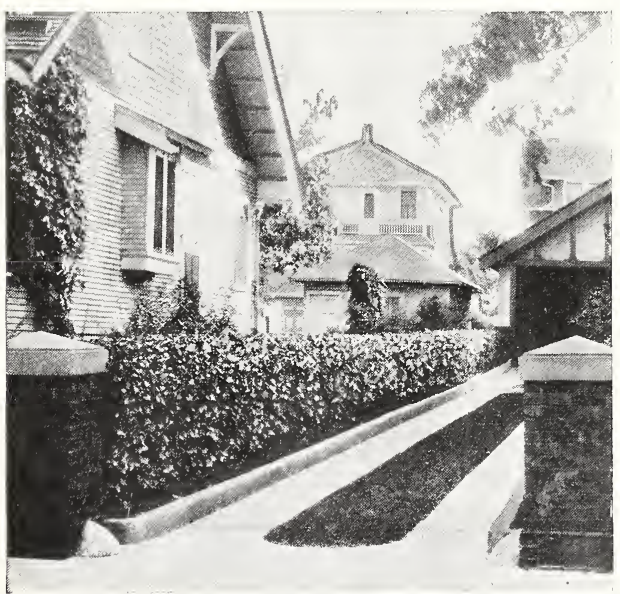

A Hedge Makes a Pleasing and Practical Boundary

\section{Plant a HEDGE for Privacy and Seclusion}

A HEDGE along the property line will give privacy and A seclusion. We will gladly suggest the kind best suited to your use and give full planting instructions. (25 Hedge Plants sold at the 100 rate.)

BARBERRY, Thunberg's - The best dwarf- 10 growing hedge. Place the plants one foot apart. 12 to 18 inches. $\$ 3.00 \$ 25.00$ 18 to 24 in. Bushy plants.

BUCKTHORN (Rhamnus Cathartica)-Makes

a thick, dependable hedge. Space the plants one foot apart.

2 to $3 \mathrm{ft}$. Bushy plants.

$3.00 \quad 22.00$

3 to $4 \mathrm{ft}$. Bushy plants.

COTONEASTER (Quinceberry) - A very orna-

mental and neat hedge of medium height.

2 to $3 \mathrm{ft}$. Bushy plants.

HONEYSUCKLE, Tartarian

2 to $3 \mathrm{ft}$. Bushy plants.

$5.00 \quad 40.00$

3 to $4 \mathrm{ft}$. Bushy plants.

SPIRAEA VAN HOUTTEI (Bridal Wreath) 2 to $3 \mathrm{ft}$. Bushy plants 3 to $4 \mathrm{ft}$ Bushy plants. 


\section{ENJOY YOUR YARD Make It Your Outdoor Living Room}

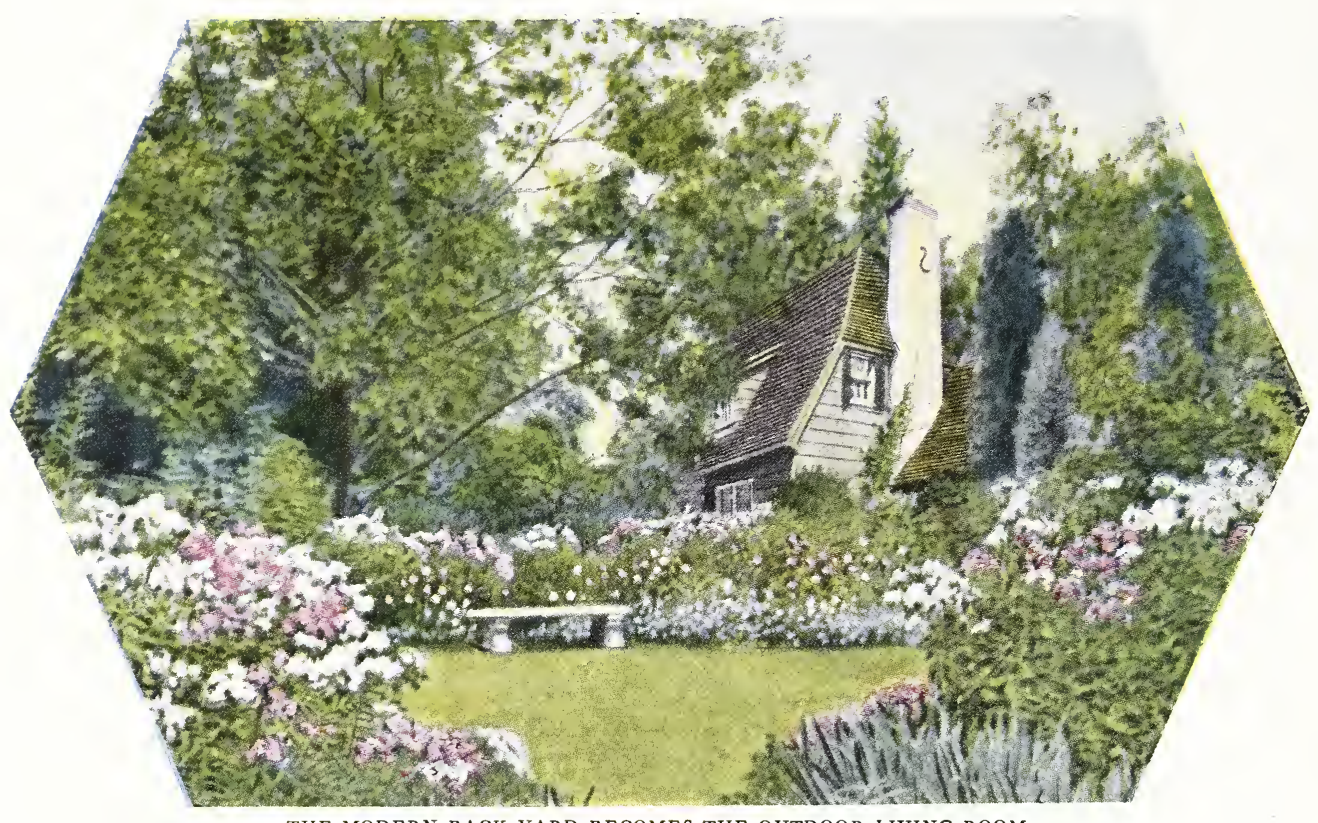

THE MODERN BACK YARD BECOMES THE OUTDOOR LIVING ROOM

THERE are hours of real pleasure and enjoyment waiting for you right in your own back yard if you will make it attractive and inviting to use. By careful planning and through only a moderate amount of landscape planting you can create right at your own door a charming outdoor living room that will become the rest and play area for all the family.

WEIHELP YOU PLAN - Calls for consultation and advice will be made by our landscape architects to any Twin City address without charge. Telephone our "Landscape Service Dept." for convenient appointment.

\section{A Special "Plan-by-Mail Service"}

Out of town customers can enjoy the advantages of our skilled designer's suggestions.

Send us a sketch plan of your property showing the location of house, walks, trees and other features. We will suggest ways of improving and beautifying the grounds so that you will get the most attractive results.

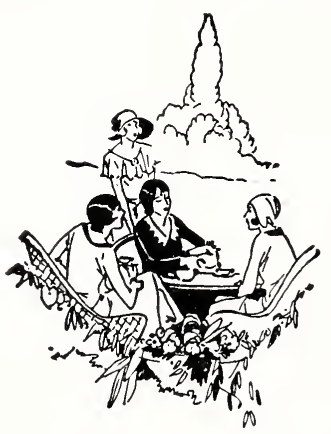

MODERNIZE YOUR YARD-A little remodeling, often made at small expense, will add tremendously to the beauty and usefulness of the older lawns and gardens. Let us help you arrange some new garden pleasure, such as a pool, rockery, rose plot or perennial border. Consult us. Ask for suggestions.

\section{HOLM \& OLSON, INC.}

\section{The Park Nurseries. Landscape Architects}

